Full-text Available Online at www.ajol.info and www.bioline.org.br/ja
J. Appl. Sci. Environ. Manage. June 2013

Vol. 17 (2) 203-223

\title{
Atmospheric pollution from the major mobile telecommunication companies in Tanzania
}

\author{
*11M. KASEBELE; W. J. S. MWEGOHA \\ ${ }^{1}$ Department of Environmental Engineering, University of Dodoma, P.O. Box 259 Dodoma, Tanzania \\ School of Environmental Science and Technology, Ardhi University, P.O. Box 35176, Dar es Salaam, Tanzania [Tel: (255) 786 316055, \\ e-mail: mwegoha@aru.ac.tzor mwegoha@hotmail.com; Fax (255) 22 2775391]
}

Keywords: Air, Base stations, Mobile Telephone, Noise, Particulates

\begin{abstract}
The extent of pollution from five major mobile telephone companies in Tanzania was investigated. These companies are Airtel, tIGO, Zantel, Sasatel and Vodacom. The parameters measured were the noise levels, NOx concentrations, and Particulate matter. The noise levels and exhaust gases were determined at 10 different Base Stations, 2 Base Stations (BSs) for each company. Results show high noise levels, with maximum hourly average of 83dB (Tigo 2 BS) and minimum hourly average of $61.4 \mathrm{~dB}$ (Vodacom BS) as compared to the permissible $45 \mathrm{~dB}$. Moreover, there is an increased noise level of hourly means of 82dB (Zantel BS), 70dB (Sasatel BS) and 72dB (Tigo 1 BS). However, concentrations of gases at the stack exit were low at all sampling points with maximum hourly average of $0.18 \mathrm{mg} / \mathrm{m}^{3}(\mathrm{NO})$ and $0.135 \mathrm{mg} / \mathrm{m}^{3}\left(\mathrm{NO}_{2}\right)$ compared to the permissible $250 \mathrm{mg} / \mathrm{m}^{3}$. The applied Gaussian model provided an approximation of the contribution of the BS generators to the atmosphere to range from $0.0006 \mu \mathrm{g} / \mathrm{m}^{3}$ and $0.001 \mu \mathrm{g} / \mathrm{m}^{3}$ (Vodacom BSs) at $300 \mathrm{~m}$ from the source to $0.35 \mu \mathrm{g} / \mathrm{m}^{3}$ and $0.014 \mu \mathrm{g} / \mathrm{m}^{3}$ at(TIGO BSs) $10 \mathrm{~m}$ from the source for both $\mathrm{NO}$ and $\mathrm{NO}_{2}$ respectively while the measured values ranged from $0 \mu \mathrm{g} / \mathrm{m}^{3}$ (Sasatel BSs) to $10 \mu \mathrm{g} / \mathrm{m}^{3}$ (Vodacom BSs) for both (NO) and $\left(\mathrm{NO}_{2}\right)$ at $2.5 \mathrm{~m}$ from the source. The released levels of the $\mathrm{PM}_{2.5}$ caused a significant rise in $\mathrm{PM}_{2.5}$ level in the ambient air concentration of indoor and outdoor environments with an hourly average increase ranging from $0.04 \mathrm{mg} / \mathrm{m}^{3}$ (Sasatel BSs) to about $0.25 \mathrm{mg} / \mathrm{m}^{3}$ (Tigo BSs) above the standard of $0.1 \mathrm{mg} / \mathrm{m}^{3}$. It is concluded that there are high noise levels and particulate emissions from these companies at varying degrees. It is recommended that a minimum of $15 \mathrm{~m}$ distance between the Base stations and nearby residence be kept so as to achieve a permissible noise level of 45dB. (C) JASEM
\end{abstract}

DOI: http://dx.doi.org/10.4314/jasem.v17i2.5

In the past decade, various mobile telephone companies such as Vodacom, Zain, Zantel, TIGO, Sasatel and TTCL have been operational in Tanzania (TCRA, 2009). The functions of these companies involve erection of mobile phone base stations where the antenna are mounted, requires the use generators especially in times of power cuts and shortages. The environmental effects associated with the mobile telecommunication companies' activities include noise pollution during the use of power generators, accidental discharges and spillages during refueling or storage and air pollution as a result of exhaust gases emissions. Eventually the companies should share information on environmental performance with the community (DEP, 2008).

Currently, Tanzania has 8 mobile telephone companies doing the business. Besides, these companies are expanding the number of their installations, resulting into environmental problems as mentioned by Lingwala, (2003) or Samuelssen et al.( 2009). These include the elevated sound levels and air bone emissions coming from numerous generators that power the industry, as well as potential for groundwater pollution due to spills of oil used to fuel generators. Some mobile telecommunication companies either lack (for the case of MPs) or rely on the EMPs proposed in the EIA undertaking done for few installations. This is exercabated by lack of environmental personnel (for instance Sasatel, TIGO and Zantel). Since each industry is unique and, as a result, so are Environmental Management Plans.

Samuelssen et al,(2009 revealed significant $\mathrm{NO}_{\mathrm{x}}$ emission of about 10 to 14 grams per horsepower hour ( $\mathrm{g} / \mathrm{hp}-\mathrm{hr})$, depending on the horsepower rating. Another study by Ling'wala,(2003) proved that acceptably low levels of RF $\left(0.12378 \mathrm{~mW} / \mathrm{cm}^{2}\right.$ and $0.0012 \mathrm{~mW} / \mathrm{cm}^{2}$ compared with the acceptable limit of exposure $0.2 \mathrm{~mW} / \mathrm{cm}^{2}$ ) can be achieved from cell phone base station antennae which can not pose health risk. Due to these findings, the concern due to the possibility of health effects as a result of exposure to the radio waves transmitted by the mobile phone base stations to the users and the people living near the base stations has been cleared. Findings from this study should help the telecommunication companies to have common procedures of environmental management during their operations. This study aims at assessing the effectiveness of the results emanating from the Environmental Management and Monitoring Plans for the mobile telecommunication industry in Tanzania. 


\section{MATERIALS AND METHODS}

Site Description: The study was conducted in Dar es Salaam city, the largest commercial city in
Tanzania. Dar es Salaam is located on the eastern region of Tanzania and lies in the coast of the Indian Ocean. The sampling areas i.e. Tandale Manzese and Magomeni are shown in Figure 1.

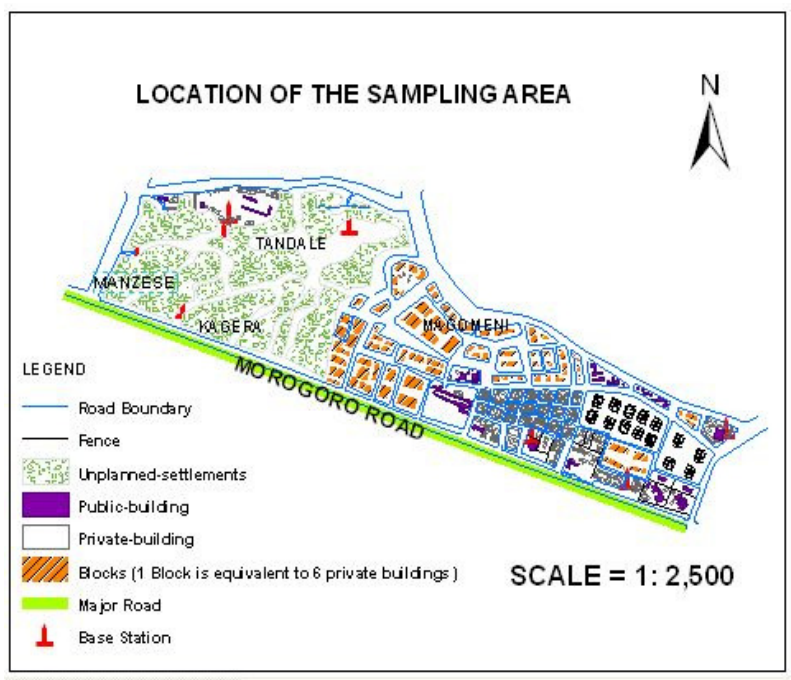

Fig. 1: Location of the Study Area

Questionnaires to residents: The sampling areas chosen are Magomeni, Manzese and Tandale wards. The areas have a total of about 170 households. The area also features a total of 15 telephone /telecommunication towers. The area is selected on the basis of documented complaints from the community to the environmental regulatory authorities on issues of elevated levels of noise, smoke emissions from the generators and the fear of the radio frequency radiations from the transmission antenna. Questionnaire survey was conducted for chosen four closest households (about 1-3m) to 14 of the base stations, making a total of 56 questionnaires.

Questionnaires to the National Environment Management Council (NEMC) Some questionnaires were administered to NEMC so as to crosscheck the information provided by the residents and the

The noise level was done using Integratingaveraging sound level meter, Bruel \& Kjaer Type 2240. This device used records the maximum noise level reached during the measurement procedure (the $\mathrm{L}_{\max }$ ) equivalent continuous sound level in seconds (Leq) and the peak sound levels( $\left(_{\text {Lpeak }}\right)$.

The meter was calibrated by placing a portable acoustic calibrator, which in this case was a sound level calibrator, directly over the microphone so that it can calibrate the meter. The sound level meter mobile telecommunication companies including the areas where the most complaints come from and the decisions made about the complaints.

Reconnaissance survey: The measurements were done at the 10 identified BSs in the identified sampling area. A survey of the surrounding area was done prior to measurements to identify the potential areas for the measurements to be taken.

Noise Level measurements: The selection of the measurement sites were based on the information rich cases (the ones providing the answer to research question and accessibility to the research data. In Table 1, various sites are chosen with respect to this criterion and the explanations of the functions are given.

Table 1: Sites Prone to noise pollution in the sampling area

\begin{tabular}{ll|}
$\begin{array}{l}\text { Measurement } \\
\text { site }\end{array}$ & Function \\
House holds & Living, resting and socializing \\
$\begin{array}{l}\text { Schools } \\
\text { Health centres }\end{array}$ & $\begin{array}{l}\text { Learning } \\
\text { Providing and acquiring health services } \\
\text { Resting, conferencing, working and } \\
\text { socializing }\end{array}$ \\
\hline libration was done before and after each
\end{tabular}

The sound level values were taken by switching on the meter and allowing it to catch the sound signals that were generated by the running generator. An

\section{KASEBELE; W. J. S. MWEGOHA}


allowance of about a minute is provided so that the sound levels values in decibels are more or less constant. The sound levels were then recorded in three mentioned positions that is the peak, maximum and the equivalent.

The sound levels were recorded in a 2(two) meter interval from the boundary wall of the BSs to the nearest household. A total distance of 10 meters was used to record the noise from the source of noise in this case the generators. Therefore a total of 5 readings were taken for each noise measurement practice.

Measurement of Stack Exhausts Gas Concentration: The instrument used for these measurements was the manual dragger pump Accuro ${ }^{\circledR}$ Pump. A manual pump using dragger tubes was used. The DrägerTubes ${ }^{\circledR} 2 / \mathrm{c}$ used can measure up to 200ppm of the $\mathrm{NO}$ and $\mathrm{NO}_{2}$ concentration in air in a single pump stroke). Prior to measurements the pump was tested to see if it properly operates by pressing the pump and placing an unpunctured tube in the pump and then releasing the pump. The pump remained in the position without returning to its normal position signifying that the pump was in good condition to be used in the measurements. A measured volume of gas that is removed from the generator as an exhaust gas was drawn through a tube which contains chemicals which change in colour in response to the presence of a gas of target gas ie $\mathrm{NO}$ and $\mathrm{NO}_{2}$ present in the sample. The drawing of the gas in the tube was in response to the striking of pump so as to remove the air in the pump. By knowing the volume of gas or air sampled, the amount of colour change read on a linear scale on the colorimetric gas detection tube can be translated into the level of gas present, described in percentage of the total air or in parts per million (PPM). This percentage was recorded as the length of the yellowish orange colour change from white in the gas detector tubes. The measurement period was 10 (ten) minutes for ten strokes and the concentrations of the $\mathrm{NO}_{\mathrm{x}}$ gases was recorded for an hour average by recording in the first 10 minutes and in the last 10 minutes that is from the $50^{\text {th }}$ to the $60^{\text {th }}$ minute.

Measurement of Stack Exhausts Gas Exit Velocity: The instrument used for these measurements was the Alnor ${ }^{\circledR}$ Velometer Series 6000P fitted with the metallic pitot probe that is used to detect the velocity of the exiting gases and the results being displayed in the analog display of the meter. The exhaust gases velocities were measured at the stack exit. Prior to measurements the instrument was checked to see if the arrow was in the zero mark whether the Velometer was in the horizontal, vertical or tilted positions. This was done using the zero adjustment screw and a screw driver. Then the range selector was adjusted to check if the readings in the meter would be similar in the two ranges that is $0-25$ and $0-50 \mathrm{~m} / \mathrm{s}$ ranges. The meter was then held with the pitot probe held direct and normal to the stack. The stack velocity was then measured by the meter in the selected range i.e. $0-50 \mathrm{~m} / \mathrm{s}$. 10 readings were taken in the half hour average every three minutes and the average value taken.

Measurement of Particulate Matter From The Exhaust Gases: The instrument used to measure particulate matter was the micro dust analyzer ie MICRODUST pro $880 \mathrm{~nm}$ fitted with filters containing probe. The device takes measurements by sensing technique of forward light scattering $\left(12^{\circ}\right.$ $\left.-20^{\circ}\right)$ using $880 \mathrm{~nm}$ infrared range of 0.001 $2500 \mathrm{mg} / \mathrm{m}^{3}$. By this narrow range of scatter the instrument sensitivity to variations in the refractive index and the colour of measured particulate is reduced.

The particulate matter $\mathrm{PM}_{2.5}$ was measured at the ambient air so that to see the generator contribution to the PM concentration of the surrounding environments. The measurements were taken before and after the generator was running in the outdoor and indoor points such as the households the nursery school and the primary school classes which were in close proximity (1-3m) to the site boundary. Before measurement the instrument was checked to see if it was correctly zeroed and that its span control (sensitivity) was correctly adjusted (it was calibrated).Calibration was done by attaching the purge to the probe purge inlet and inserting the calibration filter in the filter position and the bulb of the purge below was squeezed rapidly 6 times. An allowance of few seconds (3-5s) was given for autoranging and for the reading to stabilize. The squeezing was repeated whenever the readings did not stabilize. On entering these results the device would set the reading to zero.

The dusts measurements from the mentioned points were then done by orienting the probe and allowing the dust particles to be detected and filtered as it passes through the filter hole in the probe. The readings in the amount of the dust scattered therefore detected, was recorded and eventually retrieved using the WINDDUST pro Application software.

\section{KASEBELE; W. J. S. MWEGOHA}


The Gaussian Dispersion Model: The Gaussian dispersion model (Cooper and Alley, 1994) was used to model the concentration of the gaseous

\begin{tabular}{|c|c|c|c|c|c|c|c|c|}
\hline \multirow{2}{*}{$\begin{array}{l}\text { Stabil } \\
\text { ity } \\
\text { Class }\end{array}$} & \multicolumn{5}{|c|}{$\mathrm{x}<1 \mathrm{~km}$} & \multicolumn{3}{|c|}{$\mathrm{x}>1 \mathrm{~km}$} \\
\hline & $\mathrm{a}$ & $b^{*}$ & $\mathrm{c}$ & d & $f$ & $\mathrm{c}$ & D & $\mathrm{F}$ \\
\hline A & 213 & & 440.8 & $\begin{array}{l}1.94 \\
1\end{array}$ & 9.27 & 459.7 & $\begin{array}{l}2.09 \\
4\end{array}$ & -9.6 \\
\hline B & 156 & & 106.6 & $\begin{array}{l}1.14 \\
9\end{array}$ & 3.3 & 108.2 & $\begin{array}{l}1.09 \\
8\end{array}$ & 2.0 \\
\hline $\mathrm{C}$ & 104 & & 61.0 & $\begin{array}{l}0.91 \\
1\end{array}$ & 0 & 61.0 & $\begin{array}{l}0.91 \\
1\end{array}$ & 0 \\
\hline D & 68 & & 33.2 & $\begin{array}{l}0.72 \\
5 \\
\end{array}$ & -1.7 & 44.5 & $\begin{array}{l}0.51 \\
6 \\
\end{array}$ & $\begin{array}{l}- \\
13.0 \\
\end{array}$ \\
\hline $\mathrm{E}$ & 50.5 & & 22.8 & $\begin{array}{l}0.67 \\
8\end{array}$ & -1.3 & 55.4 & $\begin{array}{l}0.30 \\
5\end{array}$ & $\begin{array}{l}- \\
34.0\end{array}$ \\
\hline $\mathrm{F}$ & 34 & & 14.35 & $\begin{array}{l}0.74 \\
0 \\
\end{array}$ & $\begin{array}{l}- \\
0.35\end{array}$ & 62.6 & $\begin{array}{l}0.18 \\
0 \\
\end{array}$ & $\begin{array}{l}- \\
48.6 \\
\end{array}$ \\
\hline
\end{tabular}

pollutants. The general equation is provided by eqn 1.

$C=\frac{Q}{2 \pi^{*} U^{*} \delta y^{*} \delta} \operatorname{Exp}\left(-\frac{1}{2} \frac{Y^{2}}{\delta y^{2}}\right) *\left[-\frac{1}{2} \frac{(Z-H)^{2}}{\delta^{2}}+E x p-\frac{1}{2} \frac{\left(\ell(+x H \phi)^{2}\right.}{\delta z^{2}}, 0, H\right)=\frac{Q}{\pi * U * \delta y * \delta z} \operatorname{Exp}-\frac{1}{2} \frac{H^{2}}{\delta z^{2}}$

eqn 1

Where: $U=$ Wind speed at stack height $(\mathrm{m} / \mathrm{s}) ; \mathrm{Y}=$ Horizontal distance from plume center line $(\mathrm{m}) ; \mathrm{Q}=$ Emission rate $(\mathrm{g} / \mathrm{s}) ; \mathrm{C}=$ Steady state concentration at a point $(\mathrm{x}, \mathrm{y}, \mathrm{z}) \mathrm{g} / \mathrm{m}^{3} ; \mathrm{H}=$ Effective stack height (m), $\delta z, \delta y=$ Standard deviations of concentration in respect to direction measured $(\mathrm{m})$, these are functions of distance $\mathrm{x}$ and atmospheric stability; $\mathrm{Z}$ $=$ Height above the ground level $(\mathrm{m})$

The Gaussian model approximation is based on the assumption that the concentration in the atmosphere takes a normal or bell-shaped curve when the distribution of values is plotted. In the Gaussian model, dispersion coefficients are used to define the standard deviation of the concentration distribution. The dispersion coefficients used in the Gaussian model are the measures of the turbulence in the atmosphere and therefore, vary depending on the meteorological conditions, surface characteristics and distances from the source. Numerous schemes have been developed to relate atmospheric turbulence to easily measured meteorological conditions. The most common method is called the Pasquill-Gifford stability classification that uses Table 2 Values of curve-Fit Constants for Calculating Dispersion Coefficients as a Function of Downwind Distance and Atmospheric Stability

$b^{*}=0.894$ for all stability classes and values of $\mathrm{x}$ (Source: Cooper and Alley, 1976) observation of wind speed at approximately $10 \mathrm{~m}$ above the ground with solar radiation intensity (during the day) and cloud cover or vertical temperature differences (during the night) to classify the atmospheric turbulence.

A Gaussian normal distribution often results from random processes. The equation models the dispersion of a nonreactive gaseous pollutant from an elevated source. The equation is given in the form that predicts the steady state concentration at a point $(\mathrm{x}, \mathrm{y}, \mathrm{z})$ located downwind from the source(Cooper \& Alley 1994). Equation (eqn)1 gives the general equation for this model.

The Gaussian model for determination of downwind concentration of emitted pollutants is explained in equation 2;

eqn 2

Where:

$\mathrm{H}=$ Effective stack height $(\mathrm{m}) ; \mathrm{Q}=$ Emission rate $(\mathrm{g} / \mathrm{s})$

$\delta z, \delta y=$ Standard deviations of concentration in respect to direction measured $(\mathrm{m})$, these are functions of distance $\mathrm{x}$ and atmospheric stability, $\mathrm{C}$ $=$ Downwind concentration $\mathrm{g} / \mathrm{m}^{3}$

From the stability class and the receptor position, $\delta z$ and $\delta y$ may not be obtained directly from the Pasquill-Gifford curves since, the lowest values indicated in the curves is $100 \mathrm{~m}$. The formula used to calculate $\delta$, and $\delta y$ are obtained using eqn $3 \&$ 4:

$\delta z=c x^{\mathrm{d}}+\mathrm{f} \quad$ eqn 3

$\delta y=a^{b} \ldots \quad$ eqn 4

Where: $\mathrm{a}, \mathrm{b}, \mathrm{c}, \mathrm{d}$ and $\mathrm{f}$ are constant that are dependent on the stability class, $\mathrm{x}$ is distance in $\mathrm{km}$.

The mentioned values can be read in Table 2 Where: $\mathrm{a}, \mathrm{b}, \mathrm{c}, \mathrm{d}$ and $\mathrm{f}$ are constant that are dependent on the stability class, $\mathrm{x}$ is distance in $\mathrm{km}$. The mentioned values can be read in Table 2 .

Wind Velocity Calculations: The stack gas exit velocity data at site were collected at various positions from the ground level, this needed to be corrected to $10 \mathrm{~m}$ above the ground so that the stability classes could be determined. The mean wind speed is frequently represented empirically as

\section{KASEBELE; W. J. S. MWEGOHA}


a power law function of height and can be calculated using eqn 4 .

$$
\frac{u_{2}}{u_{1}}=\left(\frac{\mathrm{Z}_{2}}{\mathrm{Z}_{1}}\right)^{P}
$$

Where;

$$
\text { eqn } 5
$$

$\mathrm{u}_{2}, \mathrm{u}_{1}=$ wind velocities at higher and lower elevation respectively, $\mathrm{m} / \mathrm{s}$

$\mathrm{Z}_{2}, \mathrm{Z}_{1}=$ higher and lower elevation, $\mathrm{m}$

$\mathrm{P}=$ function of stability $(\cong 0.5$ for very stable conditions and $\cong 0.15$ for very unstable conditions).

The exponent $\mathrm{p}$ varies with atmospheric stability class and with surface roughness. Table 3 below shows various values for exponent $p$ for various stability classes. The values of the exponent chosen are based on the rough surfaces since all the measurements were done in urban environment. For flat, open country and lakes and seas, there is less variation between the surface wind and geotrophic wind.

Estimation of Pasquill Stability Classes: Stability classification is designated by letters $A$ to $F$. Stability class A, the most unstable, has the greatest dispersion potential stability, the most stable class, represents conditions that dampen turbulence, thereby reducing dispersion. Class $\mathrm{A}$ to $\mathrm{C}$ are limited to daytime where as $\mathrm{E}$ to $\mathrm{F}$ are night time conditions only. A neutral stability classification D can occur during the day or during night time periods. Table 4 gives various stability classes with respect to sky condition

Table 3 Exponents for wind Profile (power law) model for rough surfaces

Plume Rise Prediction: The analytical methods for predicting the concentration of stacks effluents involve the location of a virtual or equivalent origin. Elevation $\mathrm{H}$ of the virtual origin is obtained by adding, the plume rise $\Delta h$ to the actual height of the stack (h). There are numerous methods for calculating $\Delta h$, basically three sets of parameters control the phenomenon of a gaseous plume injected into the atmosphere from a stack. These are stack characteristics, meteorological conditions and the physical and chemical nature of the effluent. In this study the plume rise was calculated using Moses and Carson for unstable condition equation provided in equation 7 (Cooper \& Alley, 1994), other equations i.e. eqn $8 \& 9$ are used to determine the mass flux and the area of the stack.

\section{KASEBELE; W. J. S. MWEGOHA}

\begin{tabular}{|l|l|}
\hline $\begin{array}{l}\text { Stability } \\
\text { class }\end{array}$ & Exponent (p) \\
\hline A & 0.15 \\
\hline B & 0.15 \\
\hline C & 0.20 \\
\hline D & 0.25 \\
\hline E & 0.40 \\
\hline F & 0.60 \\
\hline
\end{tabular}

(Source: Cooper and Alley1994)

Sources of the stability classes are the estimations according to the atmospheric conditions

\begin{tabular}{|c|c|c|c|c|c|}
\hline \multirow{2}{*}{$\begin{array}{l}\text { Surface } \\
\text { Wind } \\
\text { at } 10 \quad \mathrm{~m} \\
\text { above } \\
\text { the ground }\end{array}$} & \multicolumn{3}{|c|}{$\begin{array}{l}\text { Day } \\
\text { Incoming Solar Radiation }\end{array}$} & \multicolumn{2}{|c|}{$\begin{array}{l}\text { Night } \\
\text { Cloudiness }\end{array}$} \\
\hline & $\begin{array}{l}\text { Stron } \\
\mathrm{g}\end{array}$ & Moderate & $\begin{array}{l}\text { Sli } \\
\text { ght }\end{array}$ & $\geq 4 / 8$ & $\begin{array}{l}\frac{L}{3 /} \\
8\end{array}$ \\
\hline$<2$ & A & A-B & $\mathrm{B}$ & & \\
\hline $2-3$ & A-B & B & $\mathrm{C}$ & $\mathrm{E}$ & $\mathrm{F}$ \\
\hline $3-5$ & $\mathrm{~B}$ & B-C & $\mathrm{C}$ & $\mathrm{D}$ & $E$ \\
\hline $5-6$ & $\mathrm{C}$ & C-D & $\mathrm{D}$ & $\mathrm{D}$ & $\mathrm{D}$ \\
\hline$>6$ & $\mathrm{C}$ & $\mathrm{D}$ & $\mathrm{D}$ & $\mathrm{D}$ & $\mathrm{D}$ \\
\hline
\end{tabular}

Table 4 Pasquill stability classes

SOURCE; Seinfeld,1986

Legend:

A: extremely unstable $\quad$ D: neutral

B: moderately unstable E: slightly stable

C: slight unstable $\quad$ F: moderately stable

Therefore the wind speed at the stack height is obtained by eqn 6 as given below;

$4=u_{1}\left(\frac{10}{Z_{1}}\right)^{P}$

Control Of Exhaust Gases eqn 6

The equations were chosen for Wind speed between 3-5; The surface is rough urban

Equations involved;

$\operatorname{seqn} 73.47\left(\frac{V s d}{U}\right)+5.15 \quad{\left.\frac{Q}{U}\right)^{0.5}}^{0.5}$ $\dot{Q}_{\text {. eqn } 8}$.eqn 9

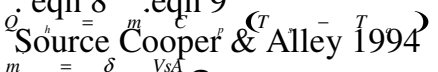

${ }^{m}=\delta_{{ }_{a}{ }^{V S A}} \boldsymbol{S}_{a}$

$C_{p}$

density of air at $32^{\circ} \mathrm{C}=1.165 \mathrm{~kg} / \mathrm{m}^{3}$ (Engineering toolbox,2005)

- pressure constant specific heat capacity of air=1.016kJ/Kg ${ }^{\circ} \mathrm{K}$ (Engineering toolbox, 2005) 
Vs-Stack exit velocity $(\mathrm{m} / \mathrm{s})$; d- diameter of the stack (m); Ts- Temperature of the exit gases $\left({ }^{\circ} \mathrm{K}\right)$; Ta- Ambient temperature $\left({ }^{\circ} \mathrm{K}\right) ; \mathrm{Q}_{\mathrm{h}^{-}}$is the heat emission rate $(\mathrm{KJ} / \mathrm{s}) ; \Delta \mathrm{h}$ - plume rise $(\mathrm{m})$

\section{RESULTS AND DISCUSSION}

Questionnaire Survey: Questionnaire survey and analysis conducted in the visited companies and the sampling areas are provided in the following sections. Out of the total of (4170) base stations of the visited companies in Tanzania the EIA procedure has been conducted to about $11 \%$ of the installations which is equivalent to 458 cell sites in Dar es Salaam. Table 5 shows some of the environmental related issues that associate the company's operations.

Table 5: Environmental Management related issues in the visited companies

\begin{tabular}{|c|c|c|c|c|c|}
\hline $\begin{array}{l}\text { Company } \\
\text { attribute }\end{array}$ & Zain & Tigo & $\begin{array}{l}\text { Sasa } \\
\text { tel }\end{array}$ & $\begin{array}{l}\text { Zant } \\
\text { el }\end{array}$ & Vodacom \\
\hline No. of B.S Tz in & 1250 & 1000 & 20 & 600 & 1300 \\
\hline No. of B.S in DSM & 143 & 400 & 20 & 98 & 390 \\
\hline No. of B.S with EIA & 68 & 200 & 20 & 14 & 24 \\
\hline $\begin{array}{l}\text { EMPs/MPs for B.S without } \\
\text { EIA }\end{array}$ & $\begin{array}{l}\text { Adopte } \\
\mathrm{d} \text { the } \\
\text { assesse } \\
\mathrm{d}\end{array}$ & $\begin{array}{l}\text { Adopte } \\
\mathrm{d} \text { the } \\
\text { assesse } \\
\mathrm{d}\end{array}$ & - & - & $\begin{array}{l}\text { Noise level } \\
\text { to addressed } \\
\text { to be be } \\
<65 \mathrm{~dB}(\mathrm{NL} \\
\mathrm{MP})\end{array}$ \\
\hline $\begin{array}{l}\text { Complaints due to } \\
\text { operations }\end{array}$ & Yes & Yes & - & Yes & Yes \\
\hline Complaints based on & $\begin{array}{l}\text {-Noise } \\
- \\
\text { Smoke }\end{array}$ & $\begin{array}{l}\text {-Noise } \\
\text {-Smoke } \\
\text {-Fear of } \\
\text { radiatio } \\
\mathrm{n}\end{array}$ & - & $\begin{array}{l}- \\
\text { Nois } \\
\text { e } \\
- \\
\text { Smo } \\
\text { ke }\end{array}$ & $\begin{array}{l}\text {-Noise } \\
\text {-Smoke }\end{array}$ \\
\hline
\end{tabular}

Residents Information: The questionnaire survey in the sampling area indicated that $86 \%$ of the respondents experience noise and smoke emission while the rest $25 \%$ responded that they experience noise only while the rest explains that they don't experience those effects (Figure 2). Moreover the questionnaire survey revealed that, $100 \%$ of the interviewed residents do not have generators for power back up. This means that the noise from the generators talked about come from of the operating
BSs. It was also noted that, $20 \%$ of the interviewed residents although they don't have power generator, they live close to other sources of noises such as flour milling machines or timber cutting machines. This makes it difficult to determine whether the noise come only from the BS operating generators or these other sources. Out of the interviewed residents $7 \%$ are from the houses surrounding the BS which EIA was done prior to project commencement

\section{KASEBELE; W ohdS. MWEGOHA}

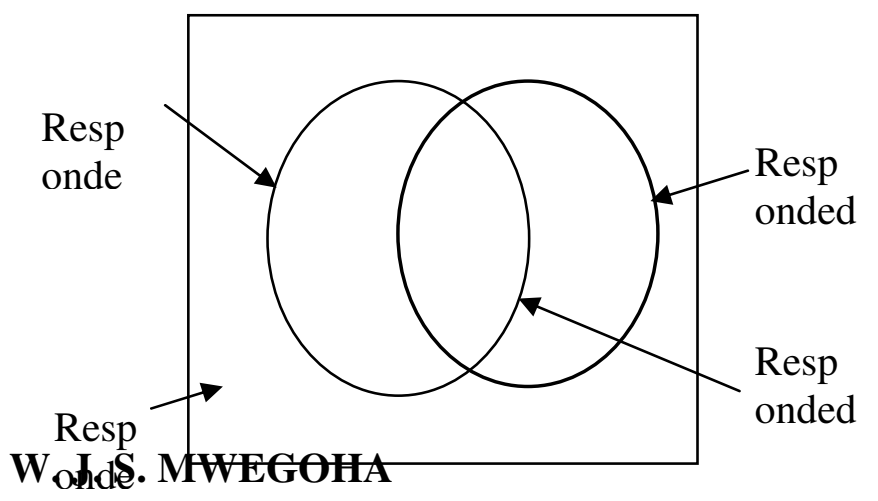




$25 \% \quad 61 \% \quad 0 \%$

Fig. 2 Environmental effects of the BSs operation

Health effects feared by the residents: Through the survey the residents also aired some of effects they think are associated with the base operations as Cancer due to radiation exposure, Skin diseases due to radiation exposure also, Respiratory complications e.g. flu, asthma attacks due to the smoke coming from the generator stacks and deafness due to noise from the running generators.

Analysis Of Noise Measurement Results From The Base Stations: The noise levels measured from the boundary wall of the Cell sites as proposed in the EIA revealed the margin of failure in the implementation of the levels proposed in the EIA or addressed in the EMP.

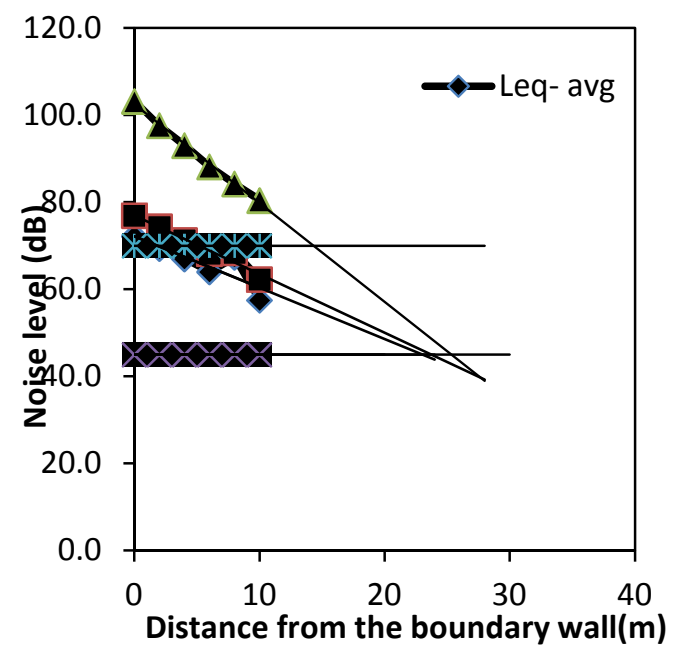

Fig. 3: Variation of noise level with distance for Zain BS

Noise Measurement Results For Tigo BSs: The two TIGO BS with tower ID Dar 147 and Dar 035 respectively also show the deviation from the noise levels value of $45 \mathrm{~dB}$ (in residential houses) as provided in the EMP as shown in figures 4 and 5. The magnitude of this deviation has been about $27 \mathrm{~dB}$ and $37.8 \mathrm{~dB}$ respectively. The two stations
Noise Measurement Results For Zain BSs: The first and second Zain BS with tower ID 10 and 464 respectively shows that the generators produce noise levels with the deviation from the noise levels value of $45 \mathrm{~dB}$ (in residential houses) and $70 \mathrm{~dB}$ ( in industrial areas). The magnitude of this deviation has been of average of about $26 \mathrm{~dB}$. This case is shown in Figure 3. According to these findings, a minimum distance of about $22 \mathrm{~m}$ is required above which the proposed noise level of $45 \mathrm{~dB}$ can be attained

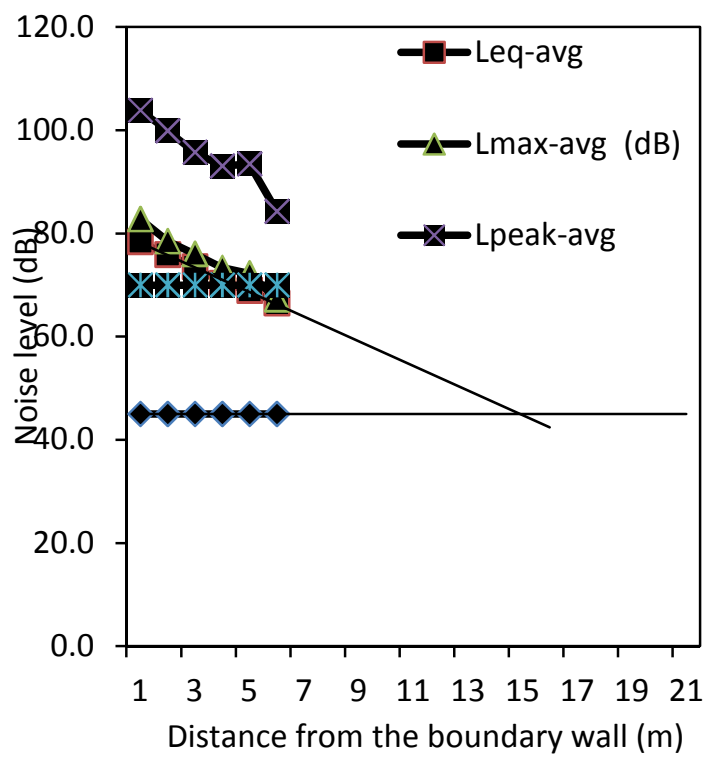

Fig. 4: Variation of noise level with distance for TIGO BS

have different types of generators of different ages and therefore the results show the difference in the noise levels. According to this an estimated minimum distance of $15 \mathrm{~m}$ and $20 \mathrm{~m}$ for each generator respectively is required to achieve the recommended noise level in the EMP.

\section{KASEBELE; W. J. S. MWEGOHA}




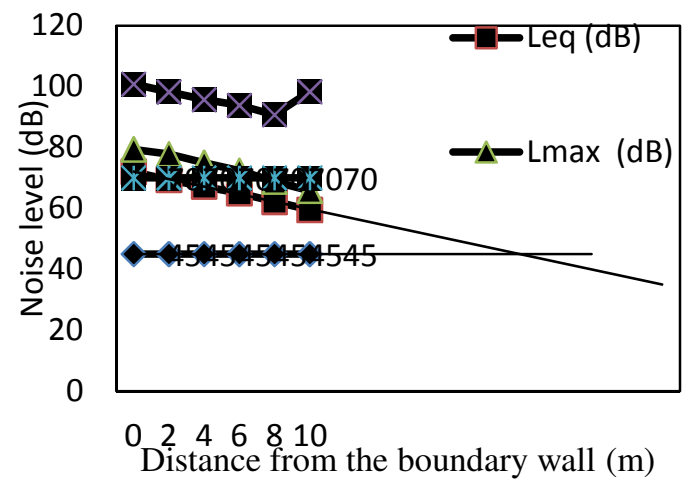

Fig. 5: Variation of noise level with distance for TIGO BS 2

Noise Measurement Results For Sasatel BSs: Results from the Sasatel BS show elevated levels of noise compared to that proposed in the EMP. The noise levels measured from two BSs with ID number Dar 18 and Dar 17 and similar making showed the levels of noises to have increased by about $25 \mathrm{~dB}$ from the proposed $45 \mathrm{~dB}$, as shown by figure 6. Again a distance of $20 \mathrm{~m}$ is required to achieve the proposed noise level in the EMP.

Fig. 6: Variation of Noise level with distance from the Sasatel BS boundary wall

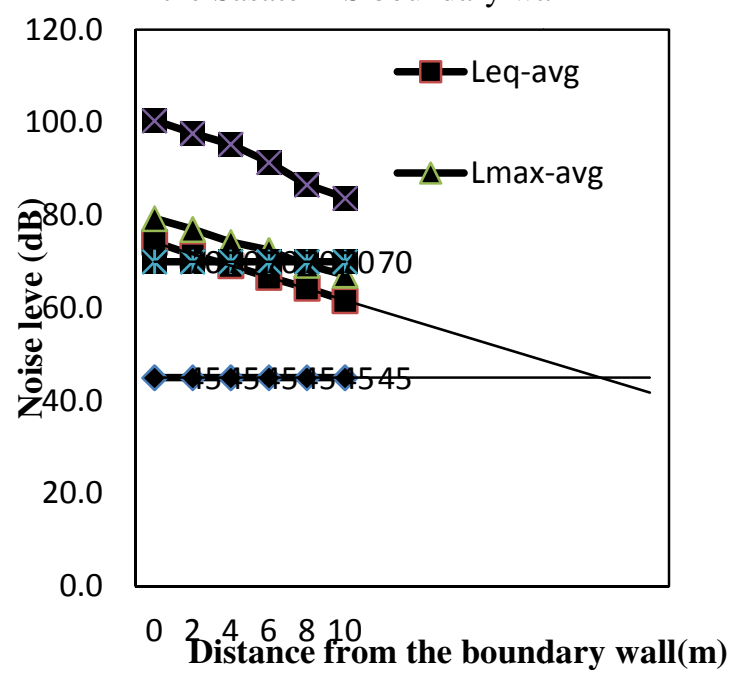

Noise Measurement Results For Vodacom BSs: Results from the Vodacom BSs generators show elevated levels of noise compared to that proposed in the EMP. Even though the deviations from the proposed EMP noise level in residential levels is a bit higher in average that is by $16.4 \mathrm{~dB}$ compared to the other companies BSs sampled, the noise level proposed in the Noise level Management Plan in the company (that is $65 \mathrm{~dB}$ ) is slightly lower than that in the EMP for industrial level. As shown in Figure 7, this is ok for the industrial areas even though is still higher than that for the residential areas especially in the case study areas where the distance from the boundary wall to the nearest households is hardly $2 \mathrm{~m}$, in other critical cases the boundary wall of the $\mathrm{BSs}$ is in close contact about $0.5 \mathrm{~m}$ to the wall of the households' bedroom. In this case a minimum distance of $18 \mathrm{~m}$ from the boundary wall is required so that the proposed noise level can be attained. 


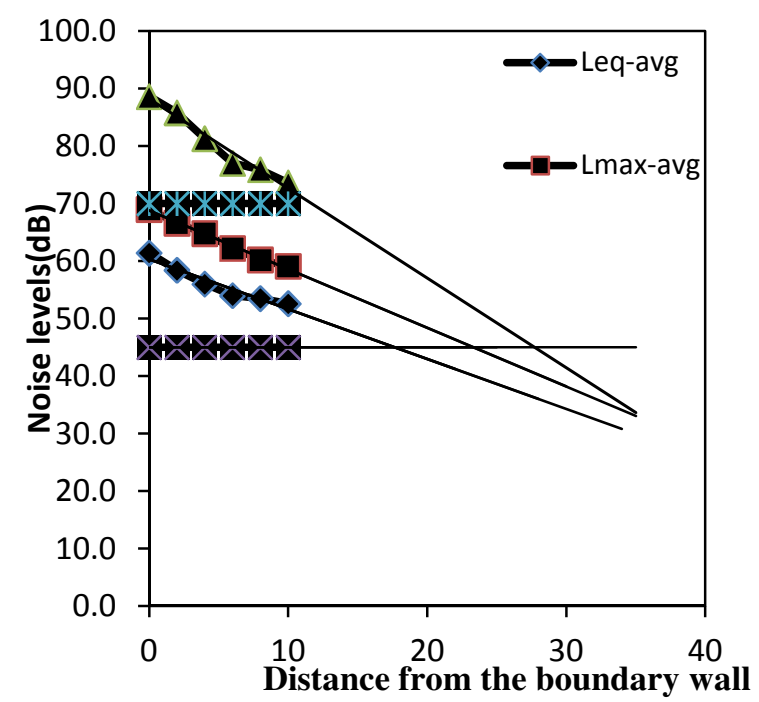

Fig. 7: Variation of Noise level with distance from the Vodacom BS boundary wall

Noise Measurement Results For Zantel BSs: Results from the Zantel BSs, as well shows the high levels of noise compared to that proposed in the EMP. The noise levels measured from two BSs generator with similar making showed an increment in the noise levels, by an average of about $37.8 \mathrm{~dB}$ from the proposed $45 \mathrm{~dB}$, shown in Figure 8 . From the analysis it is shown that a distance of about $26 \mathrm{~m}$ from the boundary wall is required from which the residents wouldn't be affected by the elevated noise, in which case the standard for the noise levels proposed in the EMP would be achieved.

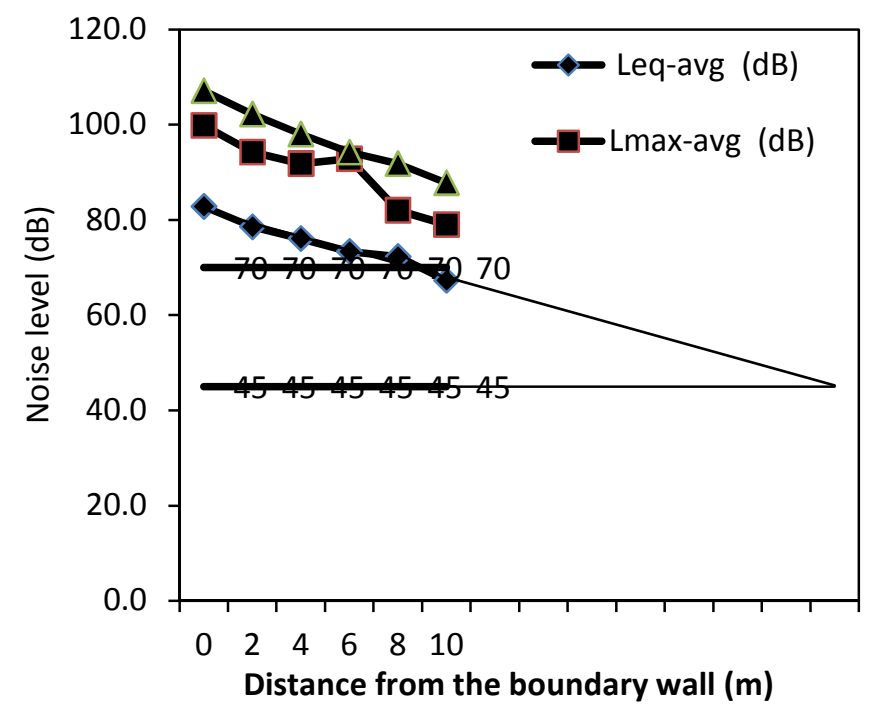

Fig. 8: Variation of Noise level with distance from the Zantel BS boundary wall

Summary of the Noise level measurement from the visited BSs: From the discussion it is seen that the level of implementation of the mitigation measures proposed in the EMPs as far as the noise levels due to the generator operation is concerned is inadequate, since the measurements for the visited companies BSs have shown the levels were higher. A minimum of $15 \mathrm{~m}$ from the BSs from the site wall is required above which the effects of noise to the residents would be negligible as indicated in Figure 9

\section{KASEBELE; W. J. S. MWEGOHA}




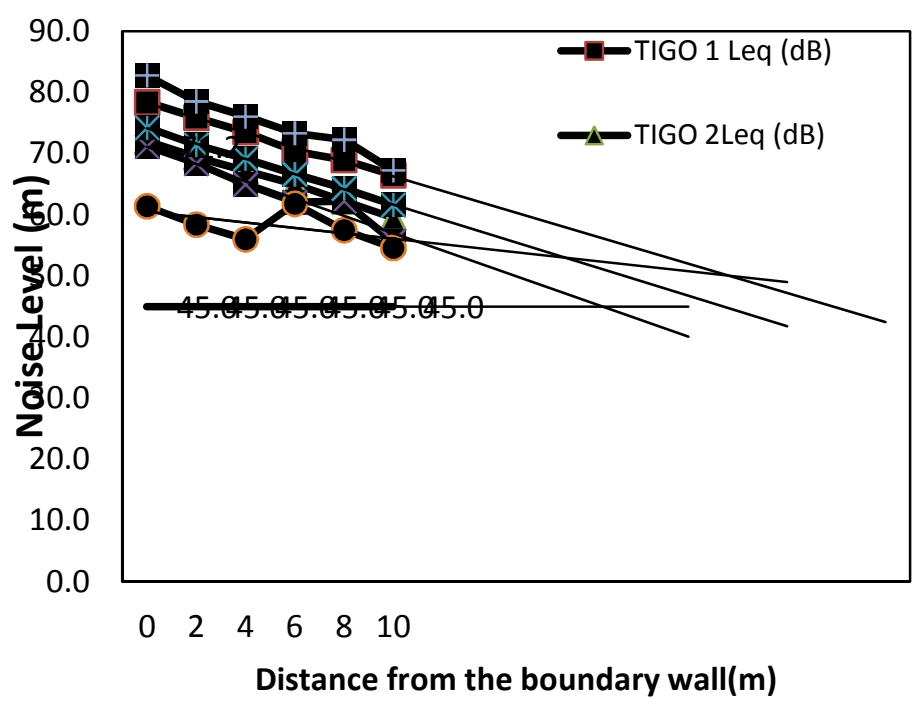

Fig. 9: Noise level with distance from the boundary wall for the visited companies BSs.

Analysis Of Measurement Gases Concentration Results From The Base Stations: The results from the measurements of the gaseous pollutant concentration show that the gases of interests in this project were below the permissible standards for the emissions from the stacks.

emission standard of $250 \mathrm{mg} / \mathrm{m}^{3}$. Figures $10 \mathrm{a}$ and $\mathrm{b}$ ) and $11 \mathrm{a}$ and $\mathrm{b}$. It was also noted that older generator
Nox Measurement Results For Tigo, Sasatel, Vodacom, Zantel And Zain Bss: The results from the mentioned base stations show that the level of the NOx (NO and $\mathrm{NO}_{2}$ ) are low with the maximum hourly mean of $0.13 \mathrm{mg} / \mathrm{m}^{3}$ for $\mathrm{NO}($ Zantel BS) and $0.08 \mathrm{mg} / \mathrm{m}^{3}$ for $\mathrm{NO}_{2}$ (Zantel $\left.\mathrm{BS}\right)$ compared to the permissible stack emitted more the noxious gas emission with an exception of the Zantel generators.

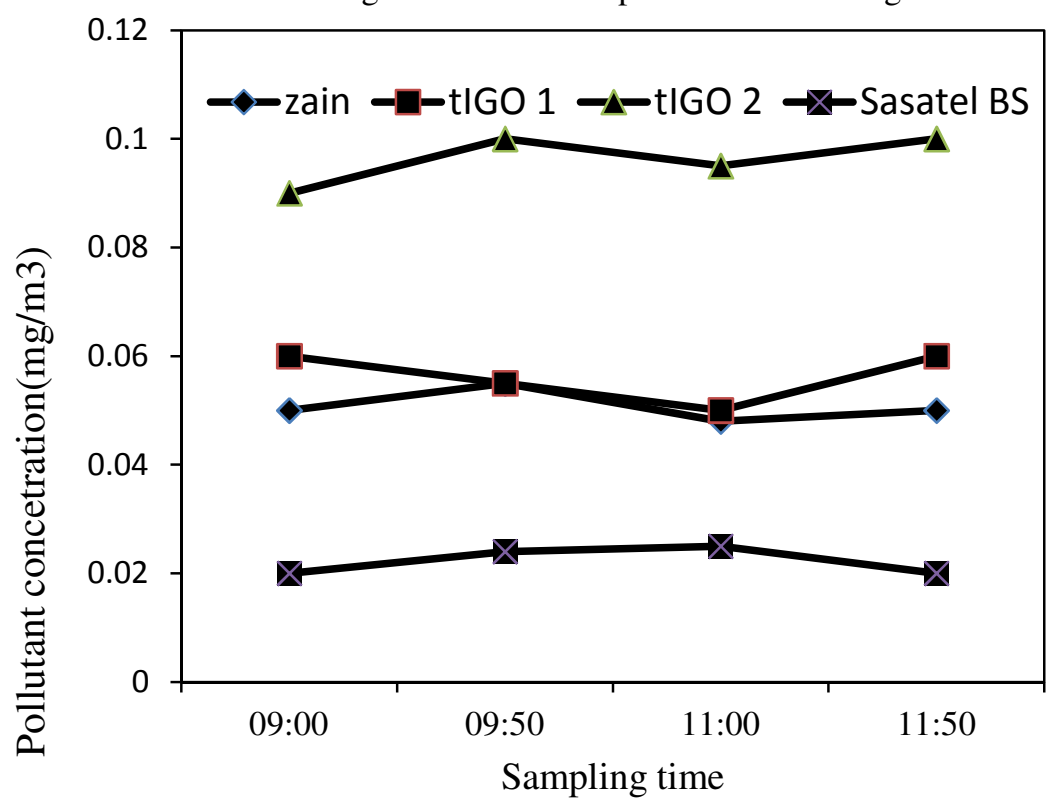

Fig. 10a) Stack NO emissions for different generator stacks 


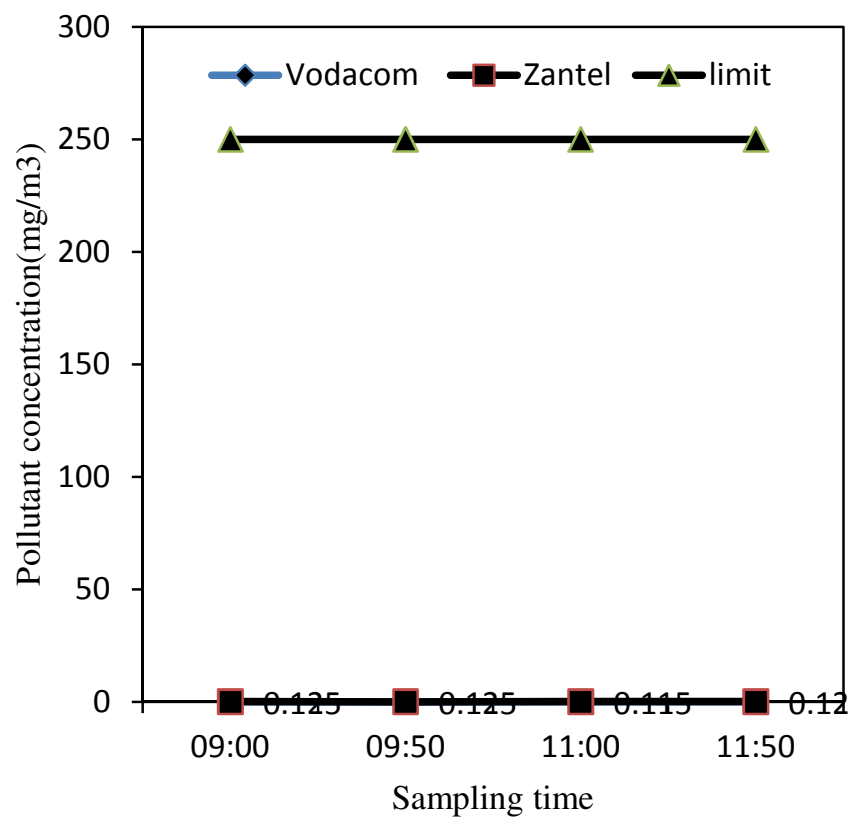

Fig. 10b NO concentration against the stack emission standard of $250 \mathrm{mg} / \mathrm{m}^{3}$

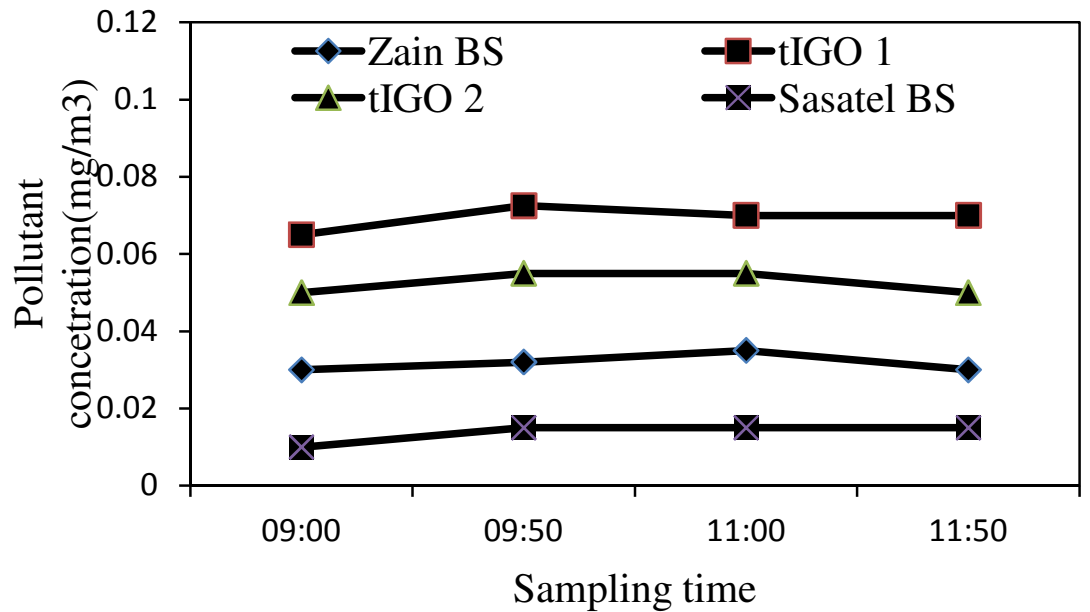

Fig. 11a Stack NO2 emissions for different generator 


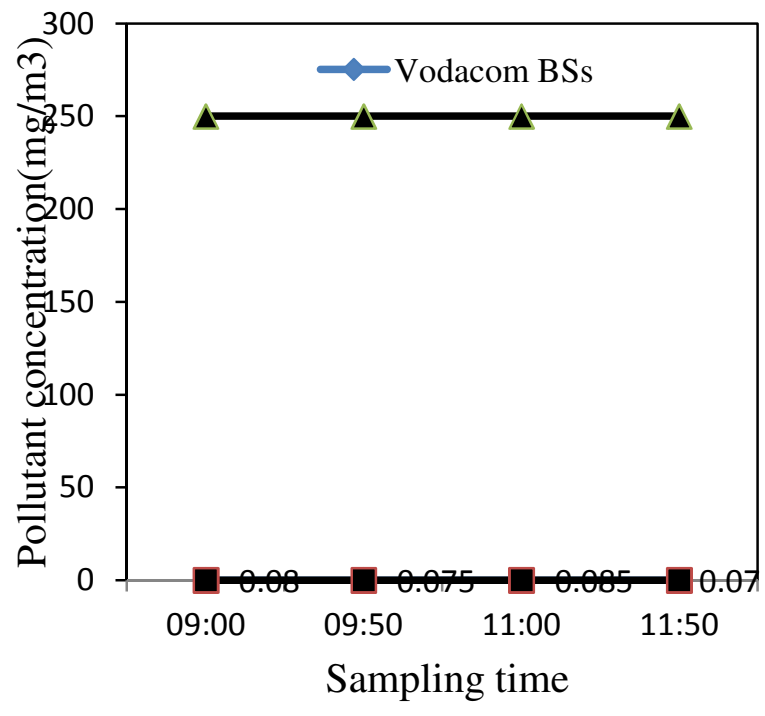

Fig.11b $\mathrm{NO}_{2}$ concentration against the stack emission standard $250 \mathrm{mg} / \mathrm{m}^{3}$

Orientation Of The Generator'stack: $60 \%$ of the surveyed generators complied with the requirements of EMP while the rest did not comply with this mitigation measure as the proposed measure in the EMP states that the stacks should be vertical and with the appropriate height to enhance effective dispersion of contaminants (particularly noxious gases and particulate matter). The Gaussian Model indicates that a sufficiently tall and vertical stack has better dispersion so that the concentration of the emitted pollutant reaching the receptor is very low.

\section{RESULTS AND DISCUSSION}

The Gaussian Air Dispersion Model : Determination of Downwind Concentration of Measured Pollutants

Gaussian dispersion model was used to predict the average concentration of NOx downwind for hourly

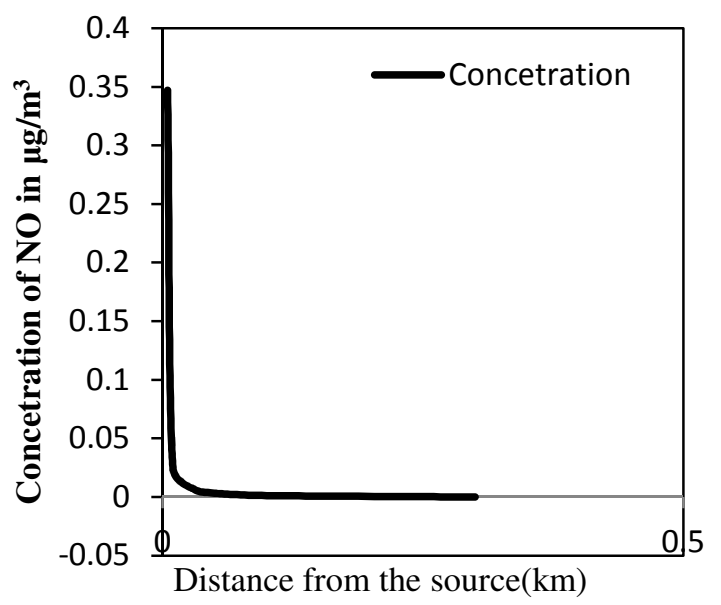

average based on the eqn 2 the same as the one provided below;

$$
C(x, 0,0, H)=\frac{Q}{\pi * U * \delta y * \delta z} \operatorname{Exp}-\frac{1}{2} \frac{H^{2}}{\delta z^{2}}
$$

Where:

$\mathrm{H}=$ Average effective stack height $(\mathrm{m})$

$\mathrm{U}=$ Average wind speed at $10 \mathrm{~m}, 4.0 \mathrm{~m}$

$\mathrm{C}=$ Downwind concentration $\mathrm{mg} / \mathrm{m}^{3}$

Model Results Tigo: The model results from the TIGO BSs showed peak NOx concentration of $0.35 \mu \mathrm{g} / \mathrm{m}^{3}(\mathrm{NO})$ and $0.014 \mu \mathrm{g} / \mathrm{m}^{3}\left(\mathrm{NO}_{2}\right)$ at $10 \mathrm{~m}$ from the source. Also the measured concentration was found to be $5 \mu \mathrm{g} / \mathrm{m}^{3}$ and $2.5 \mu \mathrm{g} / \mathrm{m}^{3}$ for both NO and $\mathrm{NO} 2$ respectively at $2.5 \mathrm{~m}$ from the source. The results both measured and modeled are shown in Figure 12.

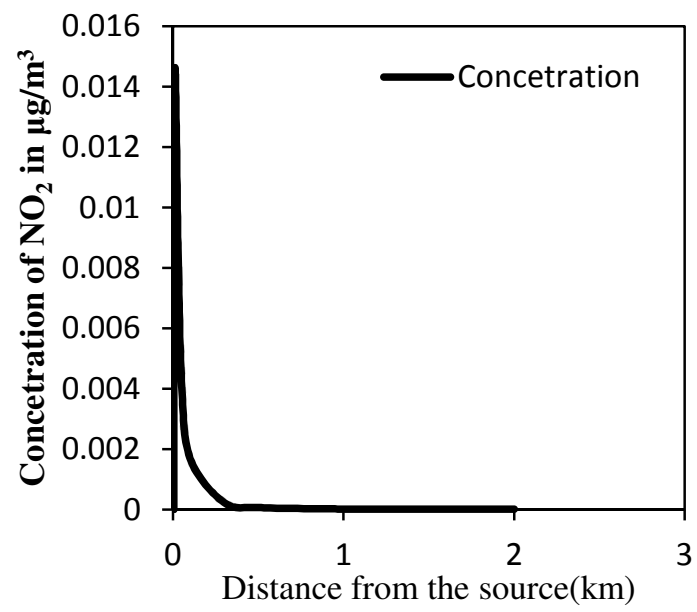

\section{KASEBELE; W. J. S. MWEGOHA}


Fig.12a The modeled NO conc. with distance b) The modeled NO2 conc. With distance

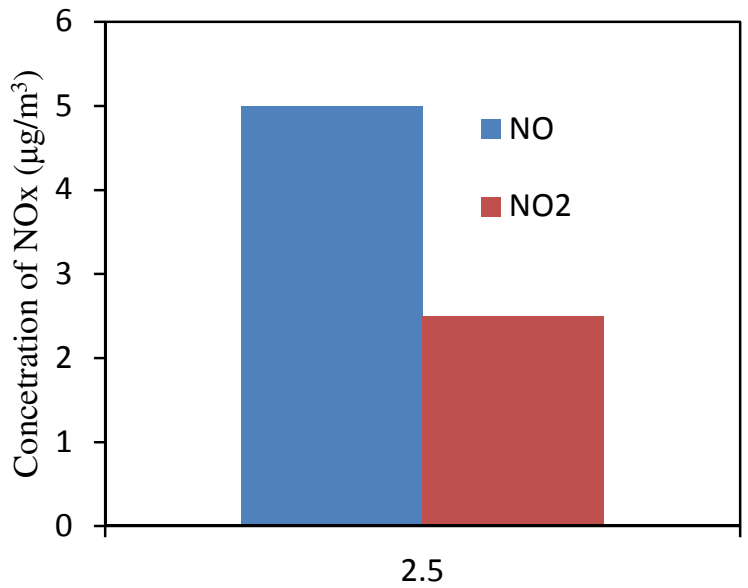

Distance from the source $(\mathrm{m})$

c) The measured NOx concentration with distance

Model Results For The Sasatel: The model results from the Sasatel showed the peak concentration of NOx of to be $0.0033 \mu \mathrm{g} / \mathrm{m}^{3}(\mathrm{NO})$ and 0.0056 $\mu \mathrm{g} / \mathrm{m}^{3}\left(\mathrm{NO}_{2}\right)$ at $10 \mathrm{~m}$ from the source. However the measured concentration did not show any detection possibly because of the instrument detection limit. The results of modeled concentration are shown in Figure 13.

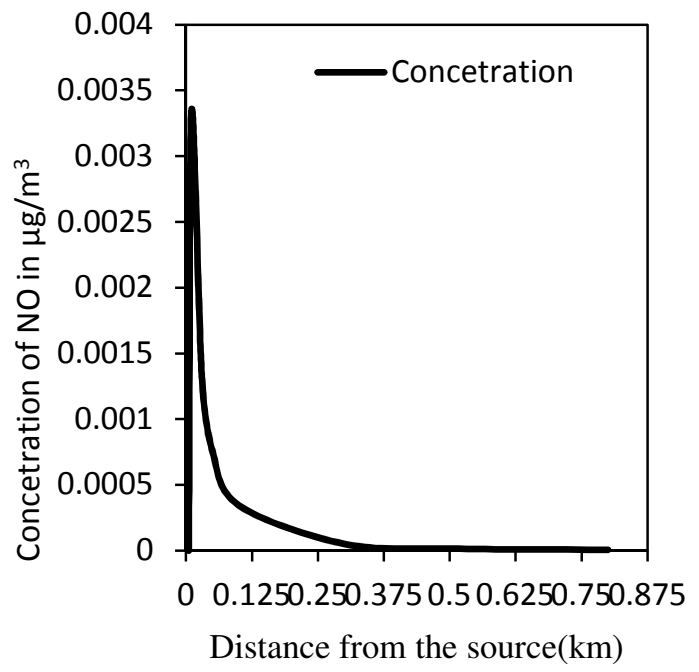

Fig. 13: Modeled NO conc. for Sasatel tower
Model Results for Vodacom: The model results from the Vodacom BSs showed peak NOx concentration of $0.0006 \mu \mathrm{g} / \mathrm{m}^{3}(\mathrm{NO})$ and 0.001 $\mu \mathrm{g} / \mathrm{m}^{3}\left(\mathrm{NO}_{2}\right)$ at $300 \mathrm{~m}$ from the source. However the measured concentration showed a peak concentration of $10 \mu \mathrm{g} / \mathrm{m}^{3}$ at $2.5 \mathrm{~m}$. The measured concentration was higher possibly due to contribution of other sources such as motor vehicles. Both measured and modeled concentration results are shown in Figure 14

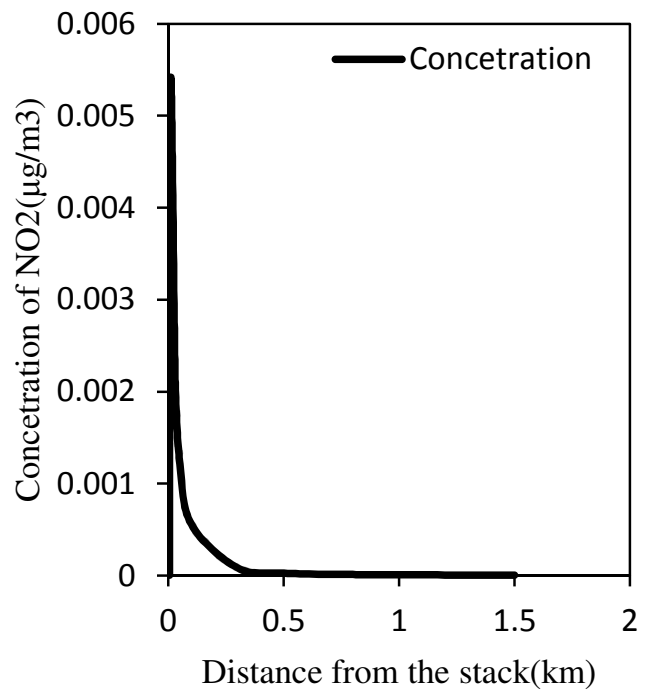

b)Modeled $\mathrm{NO}_{2}$ conc. for Sasatel tower. 

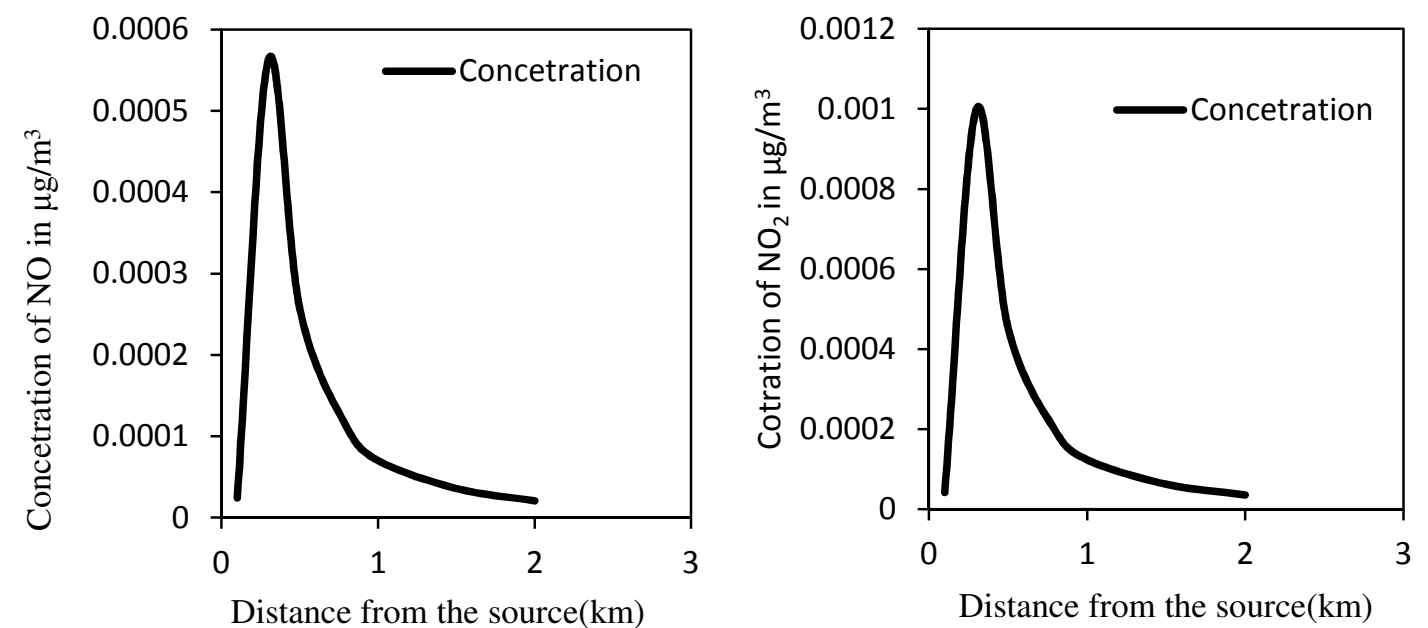

Fig. 14a Modeled conc. of NO for Vodacom b)Modeled conc. of $\mathrm{NO}_{2}$ for Vodacom BS

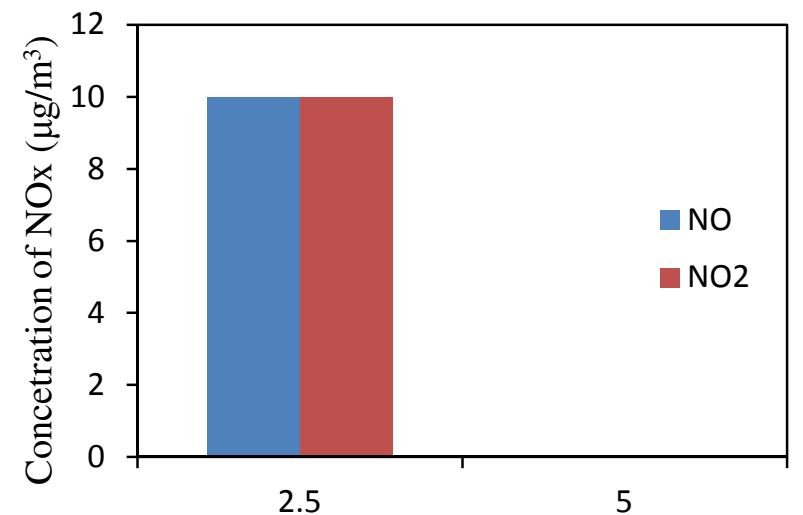

Distance from the source $(\mathrm{m})$

c) The measured NOx concentration with distance

Model Results for Zantel: The model results from the Zantel BSs showed peak NOx concentration of of $0.017 \mu \mathrm{g} / \mathrm{m}^{3}(\mathrm{NO})$ and $0.012 \mu \mathrm{g} / \mathrm{m}^{3}\left(\mathrm{NO}_{2}\right)$ at $300 \mathrm{~m}$ from the source. The measured concentration was below the instrument's detection limit. The model output is shown in Figure 15. 


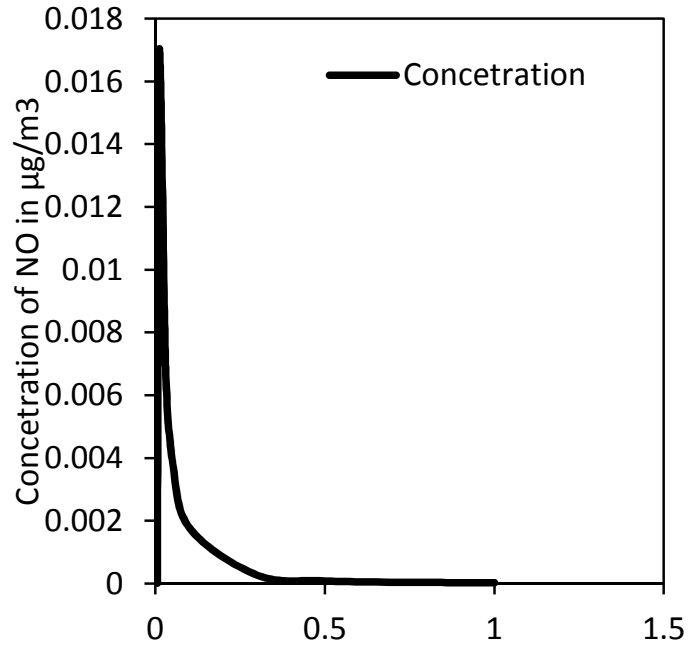

Distance from the source $(\mathrm{km})$

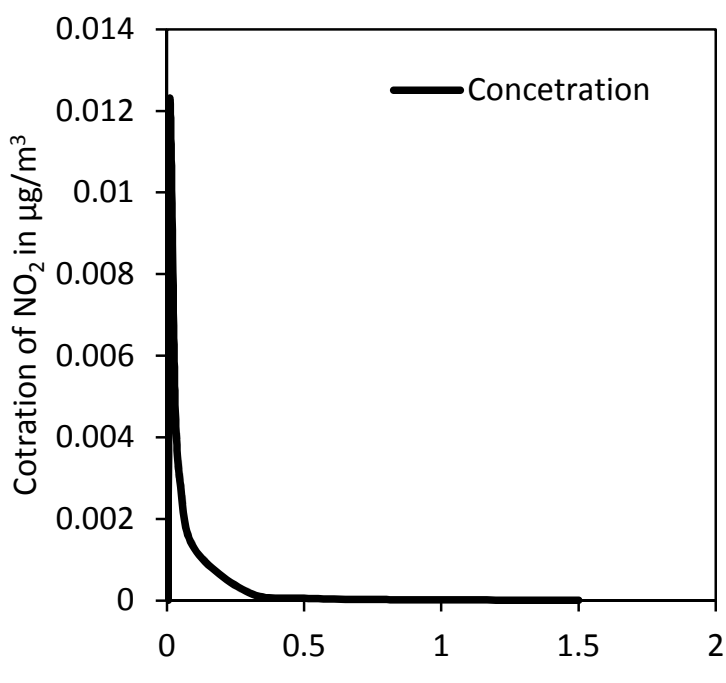

Distance from the source $(\mathrm{km})$

Fig.15a Modeled conc. of NO for Zantel b) Modeled conc. of NO2 for Zantel

Model Results For Zain: The model results from the Zain BSs showed peak NOx concentration of of $0.013 \mu \mathrm{g} / \mathrm{m}^{3}(\mathrm{NO})$ and $0.008 \mu \mathrm{g} / \mathrm{m}^{3}\left(\mathrm{NO}_{2}\right)$ at $10 \mathrm{~m}$ from the source. The measured concentration showed a peak concentration of $10 \mu \mathrm{g} / \mathrm{m}^{3}$ and $7 \mu \mathrm{g} / \mathrm{m}^{3}$ for NO and $\mathrm{NO}_{2}$ respectively, at $2.5 \mathrm{~m}$. The measured concentration was higher compared to the modeled, first, due to the difference in positions of the measured and modeled concentration given the method of measurement, but also possibly due to contribution of other sources such as motor vehicles, since these sites are located close to the street or main roads. The results of both measured and modeled peak concentrations are shown in figure 5.15
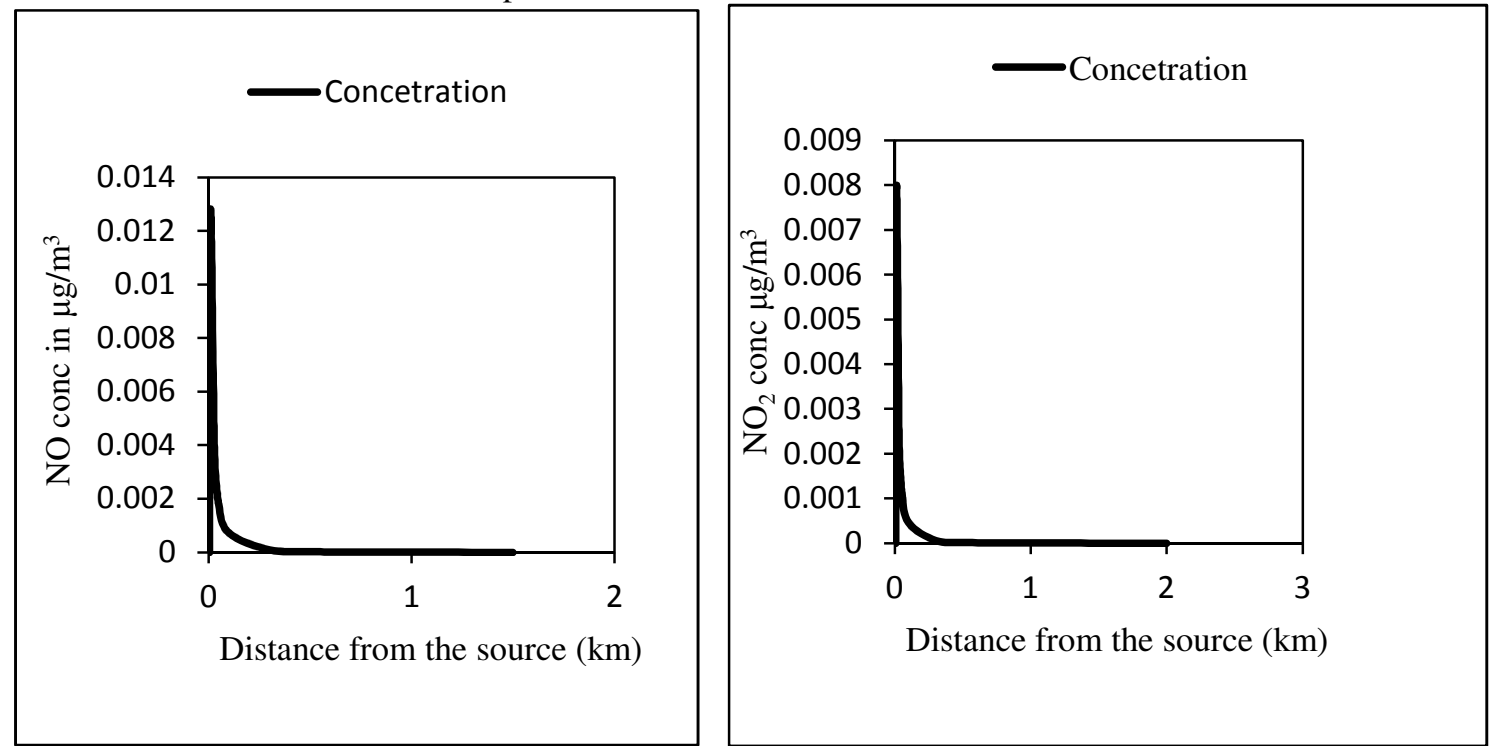

Fig. 16a Modeled conc. of NO for Zain tower b) Modeled conc. of NO2 for Zain BS 


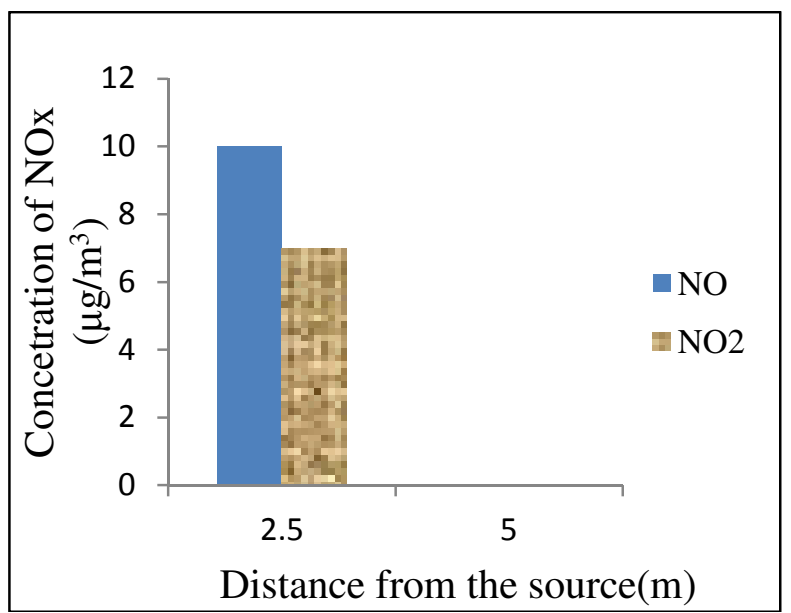

c) The measured NOx concentration with distance

Particulate Matter(Pm) Results: Tigo: The results of the stack particulate emissions for TIGO 1 and TIGO 2 BSs are as shown in figure 17 and 18, while the ratios of the indoor to outdoor are given in Tables 1 and 2. According to the results PM concentration was found to be higher after the generators had been running for both the outside and the indoor environments. This might also be caused by the orientation of the generator stack being horizontal which caused unidirectional flow of stack smoke. The ratio of the indoor to outdoor concentration was 0.5 and 0.8 , which shows that the indoor concentration was higher than the outdoor concentration for the same reason that the horizontal stacks may have influenced the concentrations in the indoor environment.

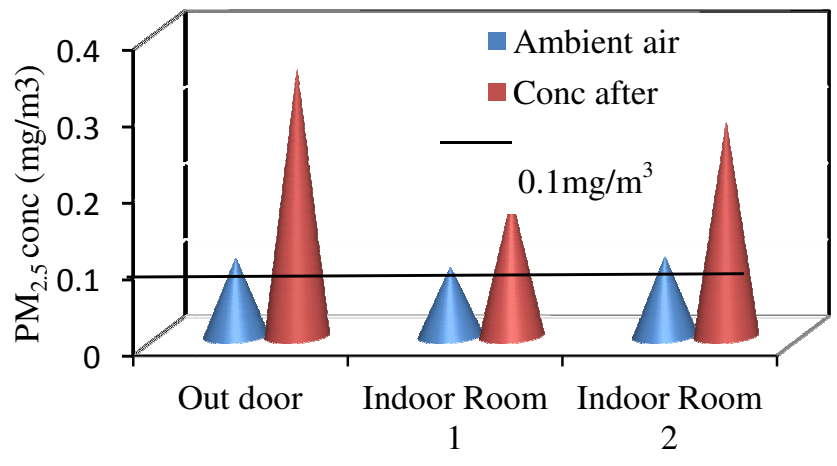

Sampling points

Fig 17: The PM concentration at Room 1\&2 and outdoor

Table 6: Ratios of PM concentrations (indoor and Outdoor) before and after the generator running

\begin{tabular}{|l|l|l|l|l|}
\hline \multirow{2}{*}{ Sampling points } & \multicolumn{3}{|l|}{ Before } & \multicolumn{2}{l|}{ After } \\
\cline { 2 - 5 } & R1 & R2 & R1 & R2 \\
\hline Indoor & 0.09 & 0.104 & 0.18 & 0.28 \\
\hline Outdoor & 0.102 & 0.102 & 0.35 & 0.35 \\
\hline Ratio In/Out & 0.88 & 1.01 & 0.51 & 0.8 \\
\hline
\end{tabular}




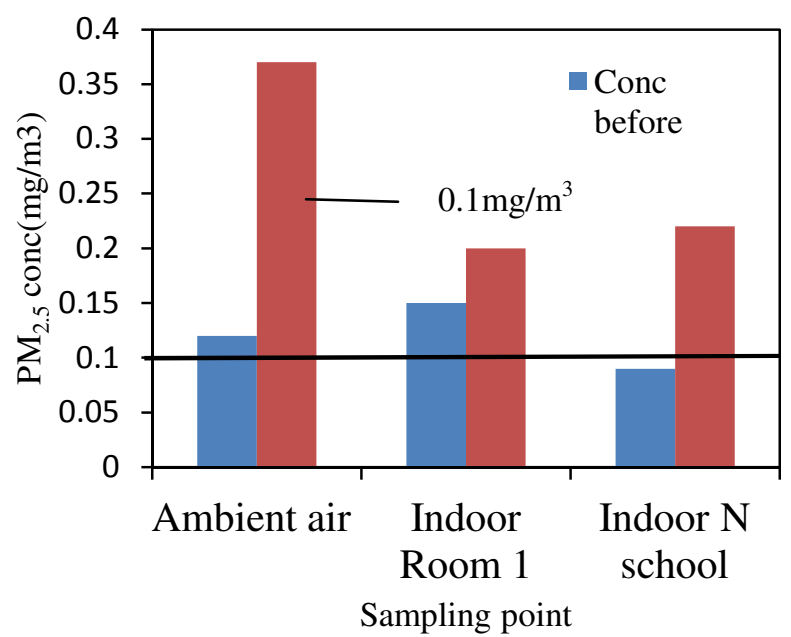

Fig. 18: The PM concentration at Room $1 \&$ Nursery school class and outdoor

Table 7: Ratios of PM concentrations (indoor and Outdoor) before and after the generator running

\begin{tabular}{|l|l|l|l|l|}
\hline \multirow{2}{*}{ Sampling points } & \multicolumn{2}{|l|}{$\begin{array}{l}\text { Before starting the } \\
\text { generator }\end{array}$} & \multicolumn{2}{l}{$\begin{array}{l}\text { lfter running the } \\
\text { generator }\end{array}$} \\
\cline { 2 - 5 } & Room 1 & Nursery class & Room 1 & $\begin{array}{l}\text { Nursery } \\
\text { class }\end{array}$ \\
\hline Indoor & 0.15 & 0.09 & 0.248 & 0.22 \\
\hline Outdoor & 0.12 & 0.12 & 0.37 & 0.37 \\
\hline Ratio In/Out & 1.25 & 0.75 & 0.67 & 0.59 \\
\hline
\end{tabular}

Zantel: The results of the stack particulate emissions for Zantel BSs are as shown in figure 19, while the ratios of the indoor to outdoor are given in Table 3. These results suggest that PM concentration was higher after the generators had been running for both the outside and the indoor environment. However the PM levels in the outside ambient air was greater than in the indoor which may have been caused by other PM sources such as the moving vehicles to and from the area, given that the place is close to the street road. The results and the ratio of the indoor to outdoor concentration was found to range between 0.53 to 0.98 for before and after sampling respectively, the closeness of the ratio to 1 during sampling might have been due to proper ventilation in the classroom.

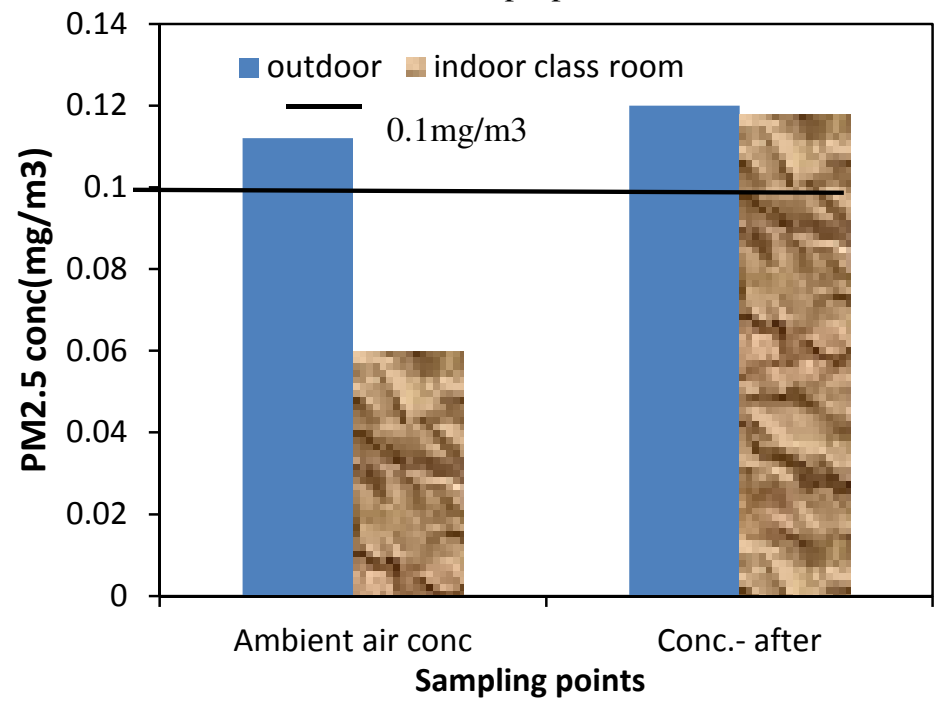

Fig. 19: The PM concentration at outdoor and indoor in class room. 
Table 8: Ratios of PM concentrations (indoor and Outdoor) before and after the generator running

\begin{tabular}{|l|l|l|}
\hline Sampling point & before & After \\
\hline Indoor class room & 0.06 & 0.118 \\
\hline Outdoor & 0.112 & 0.12 \\
\hline Ratio In/Out & 0.535714286 & 0.98 \\
\hline
\end{tabular}

Zain: The results of the stack particulate emissions in the sampled points for Zain BSs are shown in figure 20. Similar to Zantel, PM concentration was found to be higher after the generators had been running for both the outside and the indoor household. The ratios of the indoor to outdoor
PM concentrations were such that before the generator was on Household $(\mathrm{HH}) \mathrm{PM}_{2.5}$ were higher than ones after the generator running.

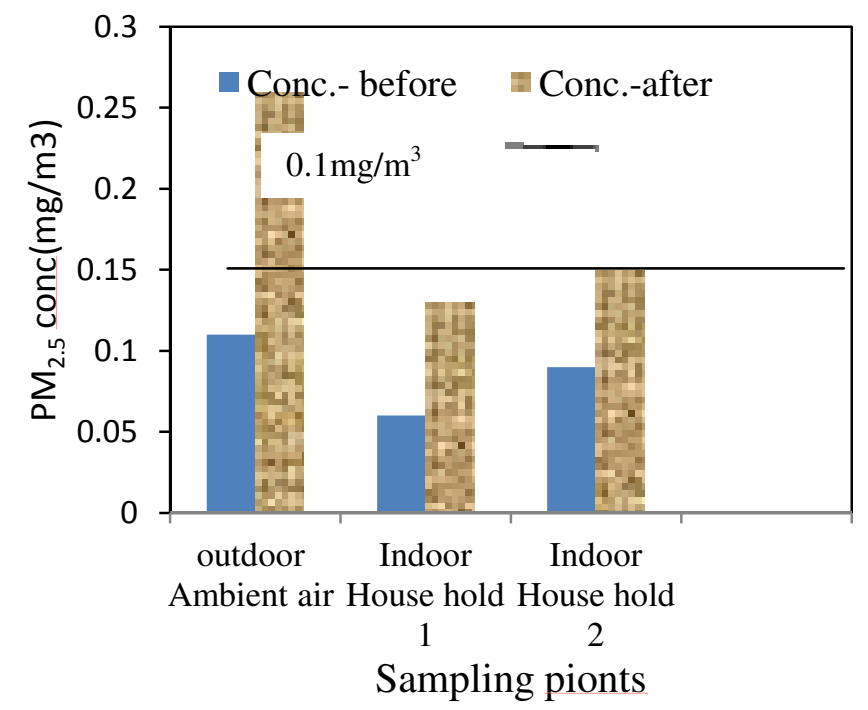

Fig. 20: PM concentration at outdoor and indoor inside 2 house holds

Table 9: Ratios of PM concentrations (indoor and Outdoor) before and after the generator running

\begin{tabular}{|l|l|l|l|l|}
\hline & \multicolumn{2}{|l|}{ Before } & After \\
\hline & & & & \\
& Indoor house 1 & Indoor house 2 & Indoor HH1 & Indoor HH2 \\
\hline indoor & 0.06 & 0.09 & 0.18 & 0.15 \\
\hline Outdoor & 0.11 & 0.11 & 0.26 & 0.26 \\
\hline Ratio In/Out & 0.54 & 0.81 & 0.69 & 0.58 \\
\hline
\end{tabular}

Vodacom: The results of the stack particulate emissions in the sampled points for Vodacom BSs are as shown in Figure 21, while the ratios of the indoor to outdoor are given in Table 5. PM concentration was found to be higher after the generators had been running for both the outside and the indoor environment. The ratio of the indoor to outdoor concentration was found to be 0.75 to 0.85 and 0.6 to 0.8 before and after running the generator for the two rooms, this shows that the outdoor concentration was higher than the indoor concentration in all cases which may have been contributed by the orientation of the generator stack being vertical so as to allow dispersion and the location of the rooms being a bit far from the source about $3 \mathrm{~m}$.

\section{KASEBELE; W. J. S. MWEGOHA}




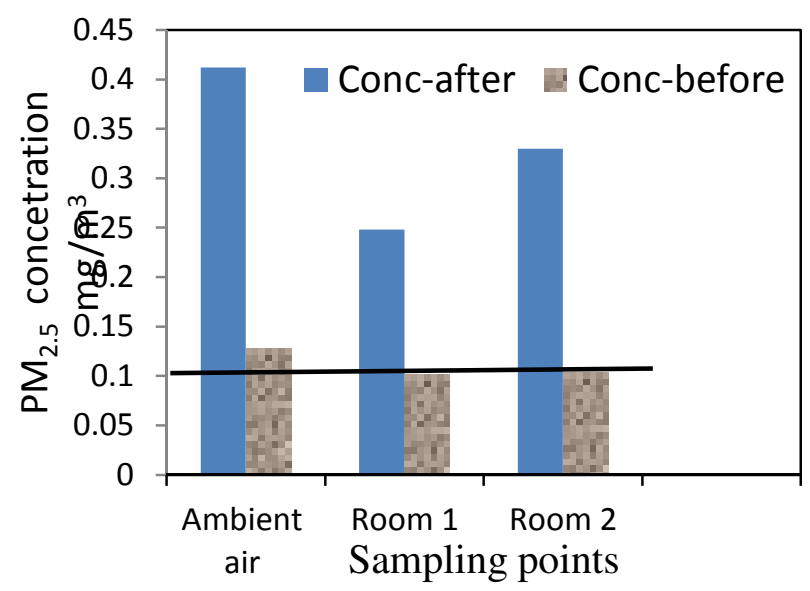

Fig. 21: The PM concentration at outdoor and indoor inside class room

Table 10: Ratios of PM concentrations (in and Outdoor) before and after the generator running

\begin{tabular}{|l|l|l|l|l|}
\hline \multirow{2}{*}{$\begin{array}{l}\text { Sampling } \\
\text { points }\end{array}$} & \multicolumn{2}{l|}{$\begin{array}{l}\text { Before starting } \\
\text { generator }\end{array}$} & \multicolumn{2}{l}{$\begin{array}{l}\text { During generator } \\
\text { running }\end{array}$} \\
\cline { 2 - 5 } & Room 1 & Room 2 & Room 1 & Room 2 \\
\hline Indoor & 0.102 & 0.11 & 0.248 & 0.33 \\
\hline Outdoor & 0.128 & 0.128 & 0.412 & 0.412 \\
\hline Ratio In/Out & 0.79 & 0.85 & 0.60 & 0.80 \\
\hline
\end{tabular}

Sasatel: The results of the stack particulate emissions at different sampling points for Sasatel BSs are as shown in figure 22 while the ratios of the indoor to outdoor are given in Table 6 . In this case the results of PM concentration were also found to be higher after the generators had been running in both the outside and the indoor environment. The ratio of the indoor to outdoor concentration showed that the outdoor concentration was higher than the indoor concentration which may also be contributed by the distance the rooms are located from the source and the stack being vertical so that dispersion was enhanced.

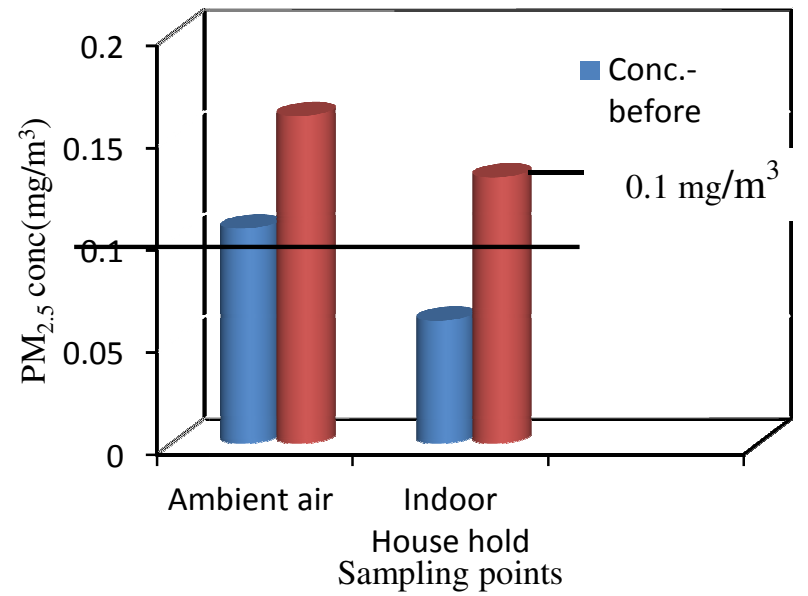

Fig. 22: The PM concentration at outdoor and indoor inside class room 
Table 11: Ratios of PM concentrations (indoor and Outdoor) before and after the generator running

\begin{tabular}{|l|l|l|}
\hline Sampling points & Before & After \\
\hline Indoor house 1 & 0.06 & 0.11 \\
\hline Outdoor & 0.105 & 0.18 \\
\hline Ratio In/Out & 0.57 & 0.61 \\
\hline
\end{tabular}

Comparison of the ambient $P M_{2.5}$ concentration between horizontal and vertical stacks. The results show that $\mathrm{PM}_{2.5}$ concentration from the horizontal

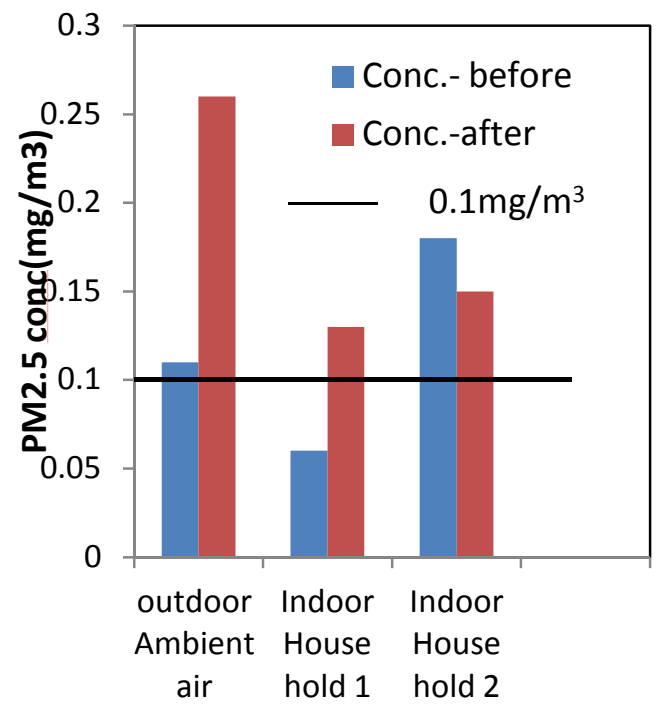

Sampling points

a

Fig. 23: A comparison of the ambient $\mathrm{PM}_{2.5}$ from the horizontal (a)

Conclusions: The mobile telecommunication sector has played a pivotal role in the country's economic development, especially enhancing instant communication. This research was set to determine potentially adverse impacts to the environment by investigating how effective the EMPs and MPs are implemented with respect to the noise, particulate and the NOx gases pollution. Noise level was found to on the higher side compared to permissible levels. In addition, the released levels of the $\mathrm{PM}_{2.5}$ caused a significant raise in PM level in the ambient air $\mathrm{PM}_{2.5}$ concentration of the surrounding (indoor and outdoor) environments with the hourly average increase of about $0.25 \mathrm{mg} / \mathrm{m}^{3}$ (Tigo BSs), 0.045 $\mathrm{mg} / \mathrm{m}^{3}$ (Zantel BSs), $0.08 \mathrm{mg} / \mathrm{m}^{3}$ (Zain), $0.23 \mathrm{mg} / \mathrm{m}^{3}$ (Vodacom BSs) and $0.04 \mathrm{mg} / \mathrm{m}^{3}$ (Sasatel BSs) above the standard of $0.1 \mathrm{mg} / \mathrm{m}^{3}$ (TBS, 2005)

The EMPs do not propose the cut of values for gaseous NOx emissions however the levels of concentration at the stack exits are low with maximum hourly average of $0.18 \mathrm{mg} / \mathrm{m}^{3}(\mathrm{NO})$ and stacks cause a greater contribution in the increased ambient PM2.5 level than those coming from vertical stack. This is shown in figure 23 .

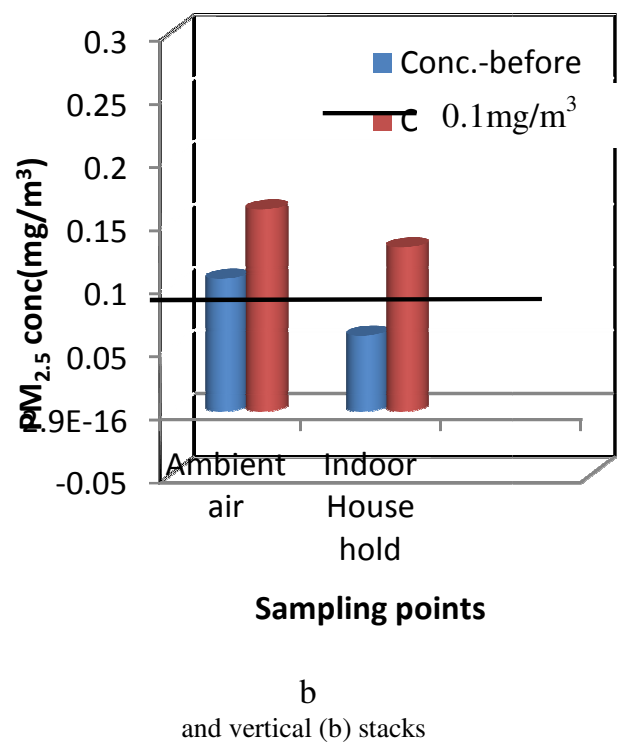

$0.135 \mathrm{mg} / \mathrm{m}^{3}\left(\mathrm{NO}_{2}\right)$ compared with the permissible standard provided by the of $<250 \mathrm{mg} / \mathrm{m}^{3}$.

The Gaussian air pollutant plume model provided an approximation of the contribution of the BS generators to the atmosphere of maximum hourly concentration of $\mathrm{NO}$ and $\mathrm{NO}_{2}$ respectively of about $0.35 \mu \mathrm{g} / \mathrm{m}^{3} 0.014 \mu \mathrm{g} / \mathrm{m}^{3}$ at $10 \mathrm{~m}$ from the source for Tigo BS, $0.0033 \mu \mathrm{g} / \mathrm{m}^{3}$ and $0.0056 \mu \mathrm{g} / \mathrm{m}^{3}$ at $10 \mathrm{~m}$ for Sasatel BSs, $0.0006 \mu \mathrm{g} / \mathrm{m}^{3}$ and $0.001 \mu \mathrm{g} / \mathrm{m}^{3}$ for Vodacom BSs at $300 \mathrm{~m}$ from the source, $0.017 \mu \mathrm{g} / \mathrm{m}^{3}$ and $0.012 \mu \mathrm{g} / \mathrm{m} 3$ for Zantel BSs at $10 \mathrm{~m}$ from the source and $0.013 \mu \mathrm{g} / \mathrm{m}^{3}$ and $0.008 \mu \mathrm{g} / \mathrm{m}^{3}$ for Zain BSs at $10 \mathrm{~m}$ from the source. The measured NOx values had hourly peak averages of $\mathrm{NO}$ and $\mathrm{NO}_{2}$ respectively of about $5 \mu \mathrm{g} / \mathrm{m}^{3}$ and $2.5 \mu \mathrm{g} / \mathrm{m}^{3}$ (Tigo BS), $10 \mu \mathrm{g} / \mathrm{m} 3$ (Vodacom BS) and $10 \mu \mathrm{g} / \mathrm{m}^{3}$ and $7 \mu \mathrm{g} / \mathrm{m}^{3}$ (Zain BS) at $2.5 \mathrm{~m}$ from the source.

\section{KASEBELE; W. J. S. MWEGOHA}




\section{REFERENCES}

City Mayors, (2006)."World's Fastest Growing Cities and Urban Areas. Available at www. citymayors.com

Cooper CD, Alley FC (1994). Air Pollution Control: A Design Approach. Waveland Press, Illinois.

DEP Division of Compliance and assistance (2009). Environmental Management Plans. Available at http://www.dca.ky.gov/kyexcel/Environmental +Management+Plans.

Environmental Management Bureau (2002). Engine Emissions - Health and Medical Effects. Available at http://www.emb.gov.ph.

Ling'wala S (2003). Radiation Exposure From Cellular Phone Base Station Antenna in Tanzania". Department of Environmental engineering, UCLAS, Dar es Salaam.
TCRA (2009). Licensing information. Available at www.tcra.go.tz

The Engineering ToolBox (2005). Air properties. Available at www.EngineeringToolbox.com

Seinfeld JH (1986). Atmospheric Chemistry and Physics of Air Pollution. Willy Inter Science, Publication, NY.

WHO (1995). WHO Guidelines for Community Noise - A complete, Authoritative Guide on the Effects of Noise Pollution on Health. Available at www.ruidos.org

Wikipedia (2010). Mobile Telephony. Available at http://en.wikipedia.org/wiki/Mobile_telephony

Samuelsen S, McDonell V, Hack RL, Phi V, Couch P, Bolszo C, Hernandez S (2009). Fuel injection and emissions characteristics of a commercial microturbine generator". Paper GT-200454039. ASME Turbo Expo. Viena. Austria. 